\title{
COMPARISON OF INSTITUTIONAL ARRANGEMENTS FOR RIVER BASIN MANAGEMENT IN EIGHT BASINS ${ }^{1}$
}

\author{
William Blomquist \\ Ariel Dinar \\ Karin Kemper
}

\section{World Bank Policy Research Working Paper 3636, June 2005}

The Policy Research Working Paper Series disseminates the findings of work in progress to encourage the exchange of ideas about development issues. An objective of the series is to get the findings out quickly, even if the presentations are less than fully polished. The papers carry the names of the authors and should be cited accordingly. The findings, interpretations, and conclusions expressed in this paper are entirely those of the authors. They do not necessarily represent the view of the World Bank, its Executive Directors, or the countries they represent. Policy Research Working Papers are available online at http://econ.worldbank.org.

\footnotetext{
${ }^{1}$ This paper is a product of the study, "Integrated River Basin Management and the Principle of Managing Water Resources at the Lowest Appropriate Level - When and Why Does It (Not) Work in Practice?” The Research Support Budget of the World Bank provided major funding. The project was carried out by the Agriculture and Rural Development Department at the World Bank. The Water Resources Management Group and the South Asia Social and Environment Unit at the World Bank have provided additional support. The study core team includes Karin Kemper and Ariel Dinar (Co-Task Team Leaders, World Bank), William Blomquist and Anjali Bhat (consultants, Indiana University), and Michele Diez (World Bank), William Fru (consultant), and Gisèle Sine (International Network of Basin Organizations). Basin case study consultants include Maureen Ballestero (Tárcoles - Costa Rica), Ken Calbick and David Marshall (Fraser - Canada), Rosa Formiga (Alto Tietê and Jaguaribe - Brazil), Consuelo Giansante (Guadalquivir - Spain), Brian Haisman (Murray Darling - Australia), Kikkeri Ramu and Trie Mulat Sunaryo (Brantas - Indonesia), and Andrzej Tonderski (Warta - Poland). Useful comments on this paper by Philip Keefer are appreciated. We are grateful to the individuals whom we interviewed in the course of this research.
} 


\section{Contents}

RIVER BASINS MAP LOCATOR

1. BACKGROUND AND INTRODUCTION ...................................................................................... 4

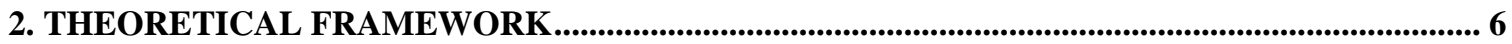

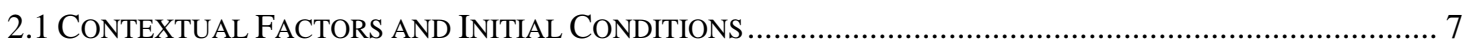

Level of economic development in the nation ............................................................................... 7

Level of economic development of the river basin ..................................................................... 8

Distribution of resources among basin stakeholders ................................................................ 8

Social and cultural distinctions among stakeholders............................................................... 9

Local experience with self-governance and service provision .................................................. 9

2.2 CHARACTERISTICS OF THE DECENTRALIZATION PROCESS ............................................................. 10

“Top-down,” “bottom-up,” or mutually desired devolution ........................................................... 10

Incorporation or involvement of existing local governance arrangements .................................... 10

Consistent central government policy commitment ........................................................... 11

2.3 CENTRAL GOVERNMENT AND BASIN-LEVEL RELATIONSHIPS AND CAPACITIES ................................. 11

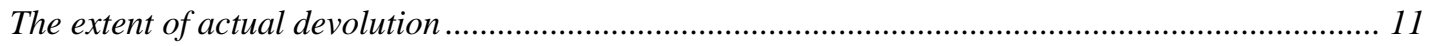

Financial resources and autonomy at the basin level................................................................ 12

Basin-level authority to create and modify institutional arrangements ............................................ 13

Distribution of national-level political influence among stakeholders ......................................... 13

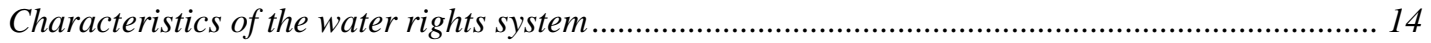

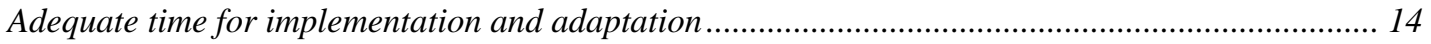

2.4 THE INTERNAL CONFIGURATION OF BASIN-LEVEL INSTITUTIONAL ARRANGEMENTS.......................... 15

Presence of basin-level governance institutions .......................................................................... 15

Clarity of institutional boundaries and match to basin boundaries................................................... 15

Recognition of sub-basin communities of interest......................................................................... 16

Availability of fora for information sharing and communication .................................................. 16

Availability of fora for conflict resolution ............................................................................... 16

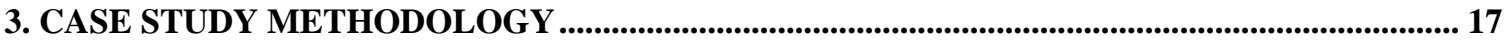

4. SUMMARY DATA ON CHARACTERISTICS OF THE RIVER BASIN ORGANIZATIONS, DECENTRALIZATION REFORMS, AND APPROACHES TO STAKEHOLDER

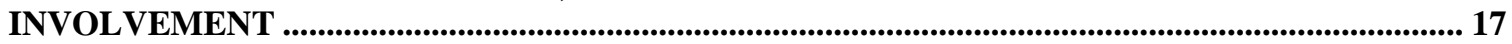

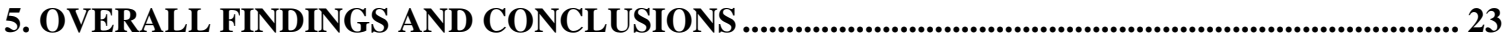

6. IMPLICATIONS FOR POLICY AND RESEARCH ..................................................................... 35

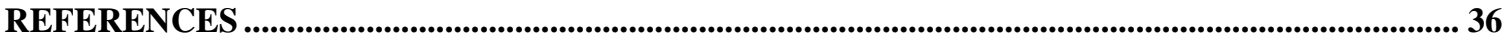

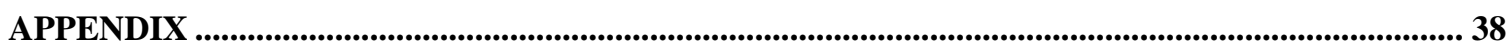




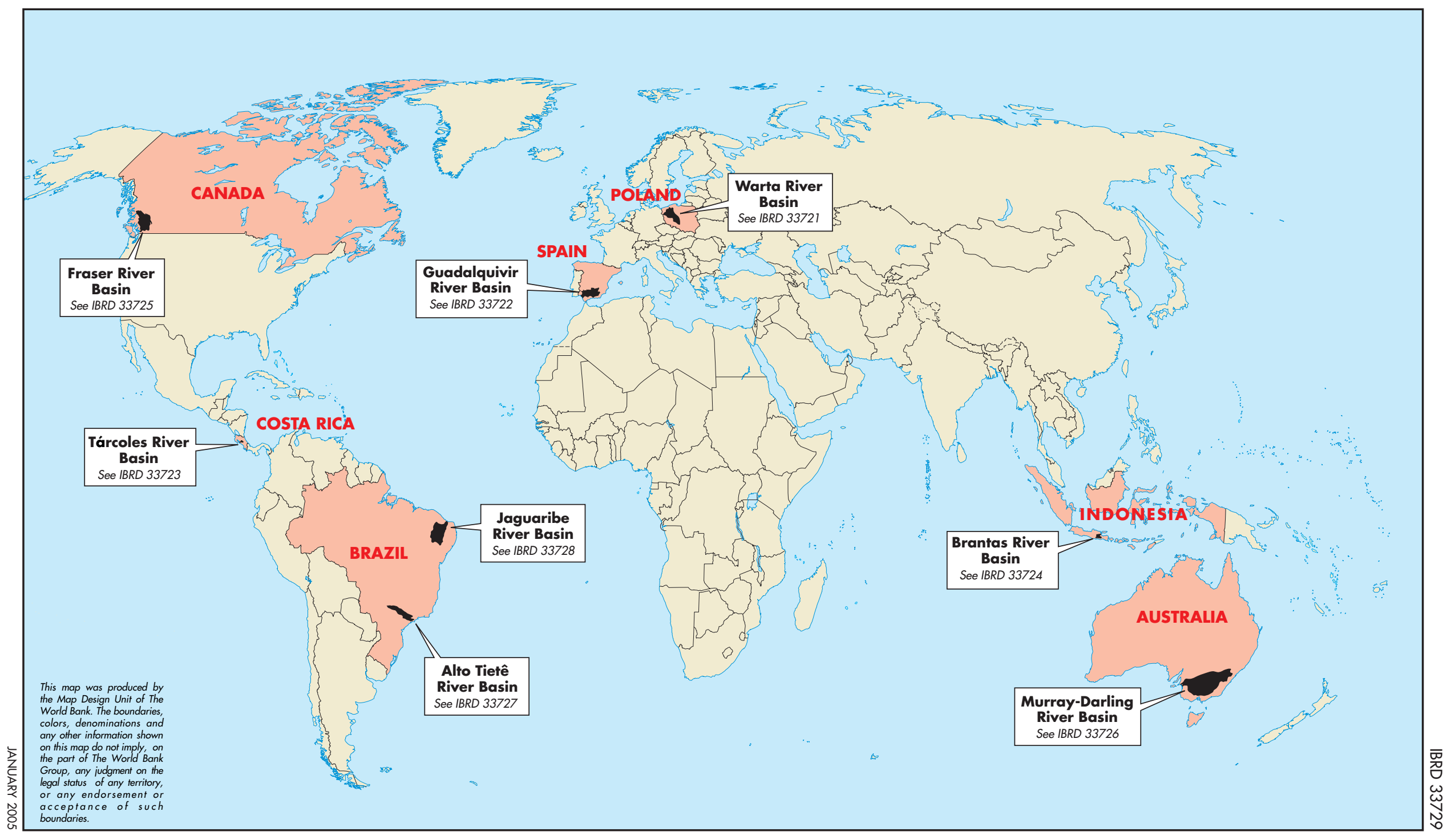




\section{Background and Introduction}

Governments in several countries, the World Bank and other multilateral financing agencies, donors and other institutions, such as the Global Water Partnership, are promoting river basin organizations in the spirit of "river basin management at the lowest appropriate level." This has especially been taking place since the Dublin Conference in 1992, which postulated that centralized approaches to river basin and water resources management had not achieved expected performance outcomes (ICWE, 1992).

Pursuing integrated water resource management (IWRM) at the river basin scale and enhancing stakeholder involvement are two of the most widely repeated recommendations in the water resources literature of the last decade if not longer. Basin management is often associated also with the concept of decentralization, of managing water resources at the "lowest appropriate level” (e.g., ICWE 1992; World Bank 1993; Mody 2004). As used in this study, decentralization has two components. One is organizing management responsibilities at the river basin scale, which often involves devolution of authority from a central government. ${ }^{2}$ The other is involving stakeholders within the basin in decision making and/or operations concerning water resource management activities.

"Stakeholders" is a convenient term that encompasses a wide array of individuals and organizations that would otherwise be awkward to identify separately for each case throughout a paper such as this one. Some stakeholders are individual water users, and others are organizations or groups of water users (e.g., utilities, industries, irrigation associations). Also, there are nongovernmental organizations that may not be directly involved with water use but have related interests in environmental protection, community development, and so on. Still other stakeholders in a basin are governmental bodies with water resource management responsibilities and authority, or with responsibilities for related concerns such as public health, environmental protection, economic development, land use, etc. Even central government officials or ministries may be stakeholders in a basin where the central government has substantial interests, facilities, or prior involvement.

Several conceptual arguments have been presented in favor of basin-level management and stakeholder involvement. These include assertions that the whole array of resources and use patterns in the basin will be taken into account, management decisions will be based on better knowledge of local conditions, and stakeholder support for and cooperation with management efforts will be greater (ICWE 1992, World Bank 1993). Stakeholder participation is believed to be related to more sustainable use of water resources and improved water management outcomes.

In connecting the organization of basin management, devolution of central government authority, and stakeholder participation, there are several related questions. What factors might affect the likelihood of stakeholder involvement really contributing to effective basin-level resource management (as distinct from mere stakeholder consultation, or the collapse of stakeholder involvement altogether)? What are the

\footnotetext{
${ }^{2}$ Usually this will be a national government, but there are circumstances where the relevant "central government" devolving authority to a basin-level organization would be a regional government such as a state or province within which the river basin is located.
} 
enabling - or disabling - conditions for effective stakeholder participation to come about? If stakeholder involvement is translated into basin-level management, how can the active involvement and effective resource management be sustained over time and changing conditions? What factors might account for the longevity of decentralized arrangements in some cases and their demise in others?

This research study is one effort to take stock of decentralization attempts in order to evaluate under which conditions decentralization has come about, and with what results. To that end, the study includes river basins where organizations have been developed at the basin scale (in some cases, sub-basin also) and where those organizations perform (or coordinate the performance of) management functions such as planning, allocation and/or pricing of water supplies, flood prevention and/or response, and water quality monitoring and improvement. The study is expected to inform decision makers engaged in on-going and planned activities in this regard, and make a contribution to improved river basin management.

Several institutional and political variables are relevant to such an effort, and are incorporated in a theoretical framework used in this study. ${ }^{3}$ The variables represent political and institutional factors that can and should be incorporated into an account of the success or failure of decentralization initiatives in water resource management. These variables and their hypothesized relationships come from theoretical and, in some cases, empirical studies of water and other natural resource management, several of which are summarized and presented in Mody (2004).

This paper presents that theoretical framework, and compares the approaches to river basin governance and management adopted in the following river basins: the AltoTietê and Jaguaribe River Basins, Brazil; the Brantas River Basin, East Java, Indonesia; the Fraser River Basin, British Columbia, Canada; the Guadalquivir River Basin, Spain; the Murray-Darling River Basin, Australia; the Tárcoles River Basin, Costa Rica, and; the Warta River Basin, Poland. ${ }^{4}$ The analysis focuses on how river basin management has been organized and pursued in each case in light of its specific geographical, historical and organizational contexts and the evolution of institutional arrangements.

\footnotetext{
${ }^{3}$ Although integrated into the discussion below of hypothesized relationships, the variables include: level of national economic development; level of basin economic development; distribution of resource endowments among basin stakeholders; cultural or other differences among individuals or groups whose cooperation or coordination is needed; histories of interactions among individuals and groups, and their anticipations about future interactions; norms of trust and reciprocity; whether decentralization initiatives were top-down, bottom-up, or mutual; involvement of existing community institutions; basin-level financial autonomy (including whether revenues generated within the basin are retained there for basin management activities); familiarity or experience of basin stakeholders with provision and management of other services or resources; whether and to what extent basin stakeholders can create or modify institutional arrangements; and adequate time for implementation and adaptation of new arrangements.

${ }^{4}$ The eight case studies employ a single theoretical framework, as part of the study "Integrated River Basin Management and the Principle of Managing Water Resources at the Lowest Appropriate Level - When and Why Does It (Not) Work in Practice?” funded by the World Bank. Policy Research Working Papers on each case study have been composed: the Guadalquivir Basin in Spain (Blomquist et al. 2004a), the Warta Basin in Poland (Blomquist et al. 2004b), the Brantas Basin in Indonesia (Bhat et al. 2005), the Tárcoles Basin in Costa Rica (Blomquist et al. 2004e), the Murray Darling Basin in Australia (Blomquist et al. 2004c), the Fraser Basin in Canada (Blomquist et al., 2004d), and the Alto Tietê and Jaguaribe Basins in Brazil (Formiga Johnsson and Kemper, 2005a, b).
} 
The cases are also compared and assessed for their observed degrees of success in achieving improved stakeholder participation and IWRM.

After this introductory section, Section 2 presents the theoretical framework applied in this research study, and Section 3 briefly explains why and how a comparative case-study approach was used to explore that theoretical framework in empirical settings. Section 4 provides an overview of some characteristics of the eight cases, and Section 5 presents our overall comparative findings and conclusions. Section 6 describes some implications of this study for future research and policymaking. An appendix contains additional information about each case in relation to four major elements of the theoretical framework.

\section{Theoretical Framework ${ }^{5}$}

Successful, sustainable, cooperative river basin management is clearly a challenge. It depends upon a combination of factors that include, at a minimum the incentives of central government officials to participate in and support the devolution of authority to basin- and subbasin-scale organizations, the incentives of stakeholders within the basin to assume and maintain responsibilities for participating in decision making and the implementation of management activities, and enabling conditions such as a legal framework and the economic resources to make the intended management improvements possible in the first place, and then sustainable over time.

Drawing upon insights from institutional analysis, and particularly from the literature relating to natural resource management and decentralized systems (Ostrom 1990, 1992; Agrawal 2000; Alaerts 1999; Bromley 1999; Easter and Hearne 1993; Wunsch 1991), the study team has identified a number of factors that may be associated with those incentives and conditions. Other analytical approaches are available for such a study-political economy, game theory, etc. The study team adopted the institutional analysis framework because its focus on institutional development as a collective outcome of individual choices made within a social, cultural and political-economic framework seemed best suited to a study intended to illuminate the origin and evolution, as well as the performance, of river basin institutions.

The team has developed a framework from which hypothesized relationships can be drawn, linking those factors to the prospects for successful river basin management in decentralized systems. In that framework, four sets of variables are identified under the following major headings:

- Contextual factors and initial conditions

- Characteristics of the decentralization process

- Characteristics of central government/basin-level relationships and capacities

- The internal configuration of basin-level institutional arrangements.

As shown in Figure 1, these sets of variables are not directly linked to basin management success or failure, but influence incentives and conditions that are believed

\footnotetext{
${ }^{5}$ A reviewer has made useful suggestions for revising the order of presentation and the names and descriptions of some of the variables in this section, which will be done in a future version of this paper.
} 
to be linked to those outcomes. In the remainder of this section, we describe the hypothesized connections between our variables of interest and the prospects for improved stakeholder participation and integrated water resource management organized at the river basin level.

Figure 1. Diagram of theoretical framework (bold=categories of variables detailed further in Section 2)

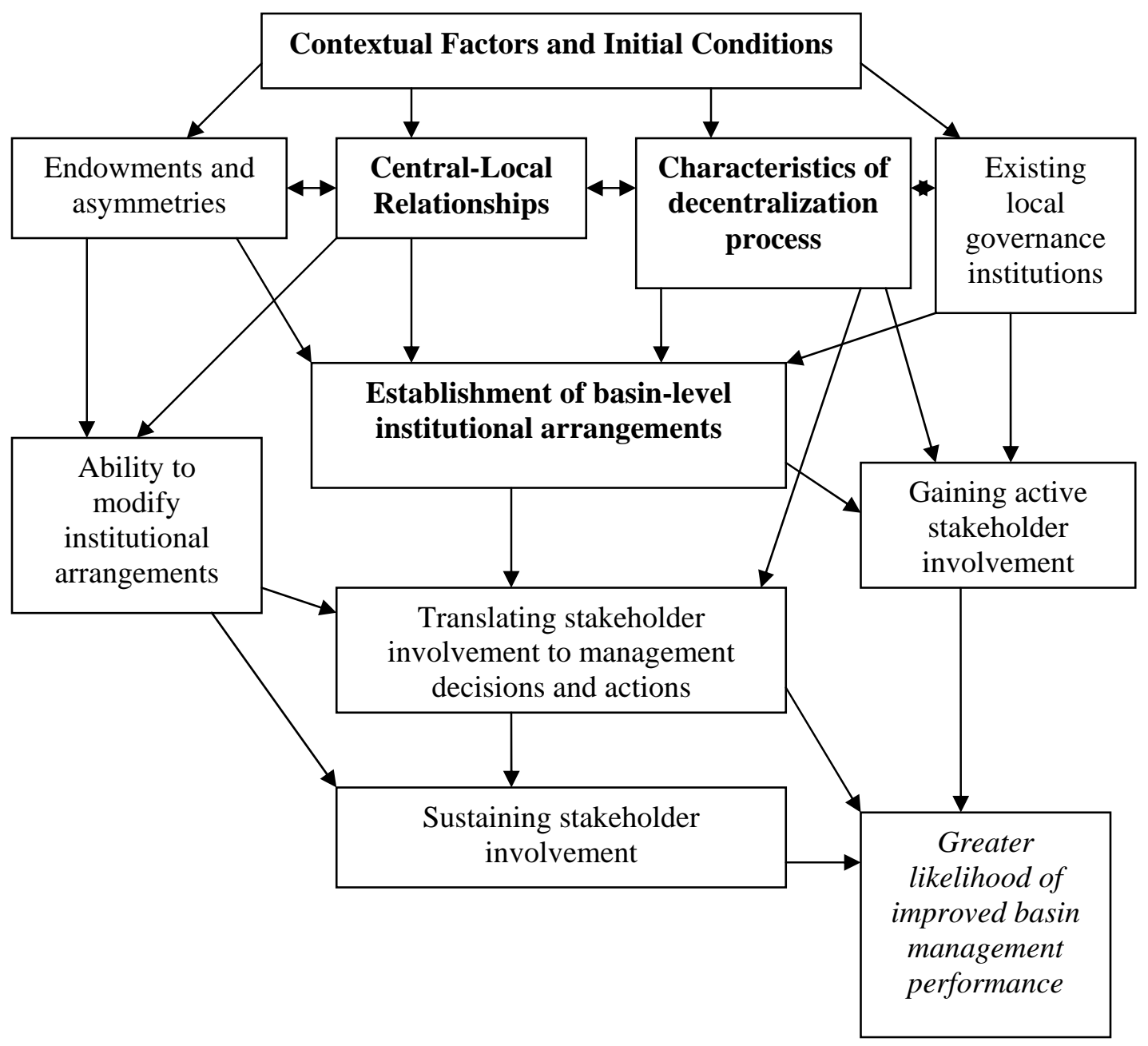

\subsection{Contextual Factors and Initial Conditions}

The literature on natural resource management indicates that successful decentralization is at least partly a function of the initial conditions that prevail at the time a decentralization initiative is attempted. These initial conditions are elements of the context of the decentralization effort.

Level of economic development in the nation

Although decentralization may be undertaken in the hope of reducing the central government's financial outlays for river basin management, the early stages of 
decentralization may be expected to require some additional outlays in order to make the transition. The central government often will need to assist basin stakeholders in establishing organizations and practices that will facilitate basin management.

Furthermore, successful decentralization does not necessarily mean terminating all central government water resource management functions. Aspects of water resource management that have the characteristics of "public goods" may be efficiently provided by a central government while other aspects of water management are devolved. Weather monitoring and forecasting are examples of such services, but hydrological research, research on the health and environmental effects of water quality, and some aspects of flood control may also fit the description. Whatever the combination in a particular location, the central government is likely to continue at least some functions and services even during and after a decentralization reform. Indeed, the success of the decentralization reform may depend upon the maintenance of those centrally provided functions.

The level of economic development of the nation is therefore an important contextual variable, to the extent that it affects the financial capacity of the central government to bear transition costs of the decentralization initiative and ongoing costs of functions that support and facilitate basin-scale management. All other things being equal, we would expect decentralization initiatives to be more likely to achieve sustainable success where the economic well-being of the nation allows the central government to bear those costs.

\section{Level of economic development of the river basin}

Decentralization also requires some commitment of financial and other resources from basin stakeholders. Developing and maintaining basin-level institutional arrangements for water allocation, water quality protection, monitoring and enforcement will not be costless. Even if the central government provides transitional or ongoing financial support, any true decentralization effort is likely to require some commitment of resources from basin stakeholders.

Furthermore, the literature on decentralized water resource management indicates that effective decentralization must include some degree of financial autonomy. Sustaining this autonomy often depends upon establishing some form of water pricing or tariffs. Implementing a water pricing or tariff regime entails requiring at least some water users to pay for a resource they previously consumed for free or at greater subsidization.

Thus, developing and maintaining the institutional arrangements for basin-level management, and implementing any form of financial autonomy, imply that some financial resources at the basin level will have to be committed to the decentralization effort. This in turn implies that basins where stakeholders can sustain those commitments are (all other things being equal) more likely to achieve sustainable success.

\section{Distribution of resources among basin stakeholders}

The literature on natural resource management also indicates that the initial distribution of resource endowments among the basin stakeholders is an important contextual factor 
in the development and successful implementation of a decentralization initiative. This variable has interesting and complex properties, however.

On the one hand and more obviously, extreme asymmetries in resource endowments among basin stakeholders can imperil decentralization success. If some stakeholders are so privileged at the outset (either financially or in terms of rights to the basin resources or political influence over allocation of the same) as to anticipate that any alteration will leave them worse off, they are unlikely to participate constructively in the decentralization process and may even try to derail it. If other stakeholders are so destitute as to be unable to bring any resources of their own to the decentralization initiative, they may rationally elect not to participate even though improved resource management would make them better off in the long run.

On the other hand and less obviously, some inequality of initial resource endowments may facilitate action by enabling some stakeholders to bear the costs of taking a leadership role. Blomquist (1988) and Ostrom (1990), for example, have identified instances in which stakeholders with greater endowments, seeing themselves as having a substantial stake in the future of the resource, were willing to bear a disproportionate share of the initial costs of organizing institutional arrangements in order to stimulate movement toward a successful and sustainable management regime.

Thus, some asymmetry of resource endowments is not necessarily fatal to a decentralization initiative, and may even facilitate it if better-situated users are willing to assume a leadership role. But extreme inequality may be detrimental or even fatal to the decentralization effort. The distribution of endowments among stakeholders is an important contextual variable affecting the prospects for successful decentralization, even if its effects cannot be hypothesized to work in a single direction.

\section{Social and cultural distinctions among stakeholders}

Class, religious, or other social and cultural distinctions can affect successful implementation of decentralization initiatives through their effects on stakeholder communication, trust, and extent of prior experience in cooperative endeavors. The greater and more contentious these distinctions, all other things being equal, the more difficult it will be to develop and sustain basin-scale institutional arrangements for governing and managing water resources. This does not mean that decentralization efforts should be made only in relatively homogeneous settings. We simply anticipate that implementation of decentralized water resource management will be more difficult in settings with significant social and cultural distinctions among users.

\section{Local experience with self-governance and service provision}

Decentralization of water resource management does not occur in a vacuum. The ability of central government officials to strike a balance between supportiveness and intrusiveness, and the capacity of stakeholders to organize and sustain institutional arrangements, will depend in part on their experiences with other public services or responsibilities. Because there are no cookbooks or recipes for "organizing water resource management at the lowest appropriate level," the ability of central and local participants to perform successfully will depend on skills they have developed in other areas of their social lives. 
We would expect that water resource management decentralization initiatives are more likely to be implemented successfully in settings where local participants have experience in governing and managing other resources and/or public services-e.g., land uses, schooling, transportation, etc. Successfully assuming local or basin-level responsibility for water resource management will not be easy under any circumstances, but it should be less daunting for local or basin-level stakeholders who are already practiced at raising, maintaining, and distributing revenues, resolving disagreements and taking collective decisions, maintaining common facilities, and so forth.

\subsection{Characteristics of the decentralization process}

Some characteristics of the decentralization process itself may affect the prospects for successful implementation. Two necessary conditions of a decentralization initiative are devolution of authority and responsibility from the center, and acceptance of that authority and responsibility by local entities in the basin. Whether both occur will depend in part upon why and how the decentralization takes place.

“Top-down,” “bottom-up,” or mutually desired devolution

Successful implementation of a decentralization initiative may depend significantly upon its motivation. In some cases, central government officials may have undertaken decentralization initiatives in order to solve their own problems-e.g., to reduce or eliminate the central government's accountability for past or current resource policy failures, resolving a budgetary crisis by cutting their financial responsibility for selected domestic policy areas, pressure from external support agencies to formulate a decentralization initiative as a condition of continued financial support, etc. In other cases, the decision to decentralize resource management to a lower and more appropriate level may have been the outcome of a process of mutual discussion and agreement between central officials hoping to improve performance outcomes and local stakeholders desiring greater autonomy and/or flexibility in managing the resource.

Of course, these examples are stated as extremes, and most actual settings would be expected to lie somewhere between. Nevertheless, all other things being equal, we can anticipate that because decentralization initiatives require active stakeholder involvement, they are more likely to be implemented successfully when devolution is desired mutually by basin stakeholders and central government officials.

Incorporation or involvement of existing local governance arrangements

The literature suggests that stakeholder involvement is likely to be greater if traditional community governance institutions and practices are recognized and incorporated in the devolution process. Because basin stakeholders already relate to their traditional community governance institutions (e.g., villages, tribes), they can be expected to be more willing to express their views on basin management, commit their resources to collective endeavors, and accept basin-level decisions as legitimate if those traditional institutions are engaged by the devolution and involved in the basin management regime. This observation has a transactions costs explanation, too: the costs (primarily in terms of time and effort) to basin stakeholders of relating to existing organizational forms are expected to be smaller than the costs of relating to an additional set of organizational arrangements. 
In contrast, decentralization initiatives that feature central government construction of new basin-level organizations that are largely separate from existing community governance institutions face higher costs in achieving stakeholders' participation, resource commitments, and acceptance of decisions as legitimate. This does not mean that no new organizations will have to be created in order to achieve basin-scale management-in fact, new organizations will often be needed to promote communication and integrate decision making across communities within a river basin. Rather, all other things being equal, decentralization initiatives are more likely to succeed in gaining stakeholder acceptance if they involve familiar governance institutions and practices.

\section{Consistent central government policy commitment}

Adoption and announcement of a decentralization policy-in the form of a statute or regulation, for instance-might occur swiftly in some cases, but in nearly all cases decentralization (which may entail adjustments to agency responsibilities, budgetary modifications, etc.) will take time. In many countries, central government regimes change periodically as elections or other processes bring different top officials or different parties into control of central government policy making. A potentially important political variable therefore is how the decentralization policy survives any transitions of central government power that occur during that period.

Broadly speaking, cases may be expected to fit one of three profiles. The first and simplest is a case where no transition of central government authority occurred during the decentralization process. The second is a case where central government transition occurred but the outgoing and incoming central government officials maintained a consistent commitment to the policy and its implementation. The third is a case where central government transition occurred but there was a noticeable discontinuity in the central government's behavior with regard to the decentralization policy.

It is not clear exactly how the implementation success of cases of the first profile would differ from those of the second, but we can expect that cases of the third type would be less likely to exhibit successful implementation of decentralization than the first two types, all other things being equal. Discontinuities in central government policy commitments can disrupt support, confuse the missions and operations of centralgovernment agencies involved in resource management, and undermine the confidence of stakeholders in the decentralization initiative.

\subsection{Central government and basin-level relationships and capacities}

Because successful decentralization requires complementary central and local actions, other aspects of the central-local relationship can be expected to condition that success. Thus, our theoretical framework considers additional political and institutional variables having to do with the respective capacities of the central government and the basin stakeholders, and with the relationship between them.

The extent of actual devolution

A decentralization policy initiative announced by a central government may be only symbolic, amounting to little more than words on paper while the central government retains in practice control over all significant resource management decisions. Worse 
still, a decentralization policy can represent an abandonment of central government responsibility for resource management without a concomitant establishment of local level authority. ${ }^{6}$ In better situations, stakeholders acquire both authority and responsibility for aspects of resource management.

These differences in the extent of actual devolution can be expected to affect the prospects for success. Symbolic or abandonment policies are at best unlikely to improve resource management, and at worst will undermine stakeholder willingness to commit to and sustain the active involvement necessary for success (e.g., Vermillion and GarcesRestropo 1998 on Colombia). Assessing the extent of actual devolution is a challenge, of course, and is more of a qualitative than quantitative undertaking. Nevertheless, we anticipate that the degree of actual devolution of resource management responsibilities to the basin level is associated with greater likelihood of success.

\section{Financial resources and autonomy at the basin level}

As noted, decentralization of resource management means at least some assumption of financial responsibilities by basin organizations and stakeholders, and some acquisition and exercise on their part of decision making authority over at least some of the financial resources they commit. If they lack autonomy to determine how funds shall be spent on resource management activities, the question is open whether meaningful decentralization has occurred.

On the other hand, decentralization does not have to mean that basin organizations and stakeholders become solely responsible for all resource management funding. In many instances, a complete transfer of financial responsibility and support for resource management from the central government to local organizations would be catastrophic for the latter and for resource management. One of the indicators of central government support for decentralization can be the central government's willingness to provide some financial assistance to basin-level organizations without intrusive control over basin-level decisions about the priorities on which those funds shall be spent.

Thus, while logic and experience suggest that basin organizations must have some financial resources and autonomy for decentralization initiatives to be implemented successfully, this is not a variable that can be arrayed unidirectionally. Rather, all other things being equal, we would expect to see the greatest prospects for success somewhere toward the middle of a spectrum where complete central government funding and control lie at one pole and complete basin-level funding and control lie at the other. ${ }^{7}$

\footnotetext{
${ }^{6}$ This is distinct from the discussion in the previous section about the motivation for the decentralization policy. A central government might adopt a decentralization policy out of sincere motivations and in consultation with local stakeholders, but nevertheless fail for other reasons to actually relinquish any control over resource management or establish local authority.

7 An optional further refinement of this variable would involve inquiring not only about the gross proportions of funding between central and local agencies but about how funding relates to resource management functions. In this refinement, successful implementation of decentralization in water resource management would be linked to central government funding and control of functions that are best organized at a larger scale because of their high capital or technical requirements (e.g., conducting hydrogeological surveys or developing water quality standards) and basin-level funding and control of functions that are best organized on a smaller scale because of their time-and-place specificity or socio-
} 


\section{Basin-level authority to create and modify institutional arrangements}

Decentralization is unlikely to succeed if undertaken with a "one size fits all” mentality. Institutional arrangements at the basin level-for governance, financing, monitoring, infrastructure construction and maintenance, etc.-are more likely to function effectively if tailored to the particular physical, social, and economic setting of each basin. They are also more likely to function effectively for long periods - to be sustainable-if they can be modified in response to changed conditions. Thus a key element is the extent to which local communities can design and implement their own institutional arrangements.

Successful implementation of decentralization is likely to be a function of that local autonomy, for two reasons. First, while it is conceivable that central government officials could successfully design and alter institutional arrangements for each basin, as a practical matter the information requirements of such a task are extremely high. Second, the ability to craft their own institutional arrangements can be expected to attract more active involvement from basin-level stakeholders compared with the option of merely assuming positions or roles in institutional settings designed by someone else. ${ }^{8}$

Plainly, the characteristics of the central-local relationship are complex, but it is a critical variable in relation to the prospects for successful decentralization. All other things being equal, we expect to find successful and sustainable implementation of decentralization initiatives more often in settings where stakeholders are empowered to craft institutional arrangements for resource management at the basin and sub-basin levels (including cross-jurisdictional arrangements), and modify them as needed.

\section{Distribution of national-level political influence among stakeholders}

The effectiveness of basin-level institutional arrangements will be a function of stakeholder commitment to them. This includes stakeholder willingness to abide for the time being by decisions or actions taken by those basin-level institutions, even when the stakeholder disagrees or would have preferred something different. This degree of commitment is essential to the maintenance of trust and reciprocity among stakeholders,

cultural implications (e.g., decisions about allocation of water between different sectors, monitoring of individuals' or households' water use, maintenance of infrastructure facilities, etc.).

8 Two extensions or implications of this logic should be mentioned. First, the creation of effective basinscale arrangements will often require the ability to establish cross-jurisdictional or inter-jurisdictional institutions, since basin boundaries may not conform neatly to the boundaries of existing political or administrative jurisdictions. Accordingly, the central-local relationship confers greater autonomy on basinlevel stakeholders to create and modify institutional arrangements for decentralized water resource management if it includes the authority to develop cross-jurisdictional arrangements than if it does not. Second, the authority to create and modify institutional arrangements may not extend only to basin-scale arrangements. Basin-level stakeholders may also discern the need for or utility of some sub-basin arrangements, and the central-local relationship confers greater autonomy on basin-level stakeholders if it also allows them to create and modify these as well. One limitation of this logic should also be mentioned. The more organizations stakeholders create, the greater the transaction costs of maintaining all of them and coordinating their activities. We do not therefore anticipate that stakeholders will create new institutional arrangements to match the scope and scale of each and every management function. They may quite rationally opt to rely on some existing institutions to conduct management functions even though boundary and other considerations seem to be less than perfectly fitted to the task, in order to limit transaction costs to a manageable level. 
which is in turn vital to the success of the basin-level institutions on which decentralized management depends.

That commitment can be undermined when stakeholders have asymmetrical access to central-government influence. If some stakeholders but not others can apply political influence with central officials to block or overturn or exempt them from basin management decisions with which they disagree, or structure advantages on their behalf relative to other stakeholders, bargaining among stakeholders over resource management decisions will not be conducted in good faith and resource management policies will not be enforced fairly. The trust and reciprocity beliefs that underlie sustainable local arrangements can be expected to erode quickly, taking the prospects for successful decentralization with them. All other things being equal, we would expect to more often find successful implementation of decentralized management in settings where stakeholders had relatively symmetrical political influence with the central government.

Characteristics of the water rights system

It may be possible to find settings where all aspects of water allocation, including (formal or informal) $)^{9}$ rights of use, are defined at the local level among basin stakeholders, but it is more likely that at least some aspects of water allocation are defined within a context of national rules establishing rights of use (or state or provincial rules in federal systems). The nature of those centrally-determined rights will have important implications for the implementation of decentralized resource management. Characteristics of water rights systems can make it easier or harder for water users to agree upon, maintain, and enforce agreements that regulate use or require contributions to collective action.

Quantification of water rights is such a characteristic. Quantified water rights systems assign rights to a particular amount of water use; non-quantified water rights systems may simply define allowed uses or establish ordinal priorities among users. Advantages of quantified rights systems include relative clarity and certainty among users about who may use what, and in the assignment of tariffs or other fees. ${ }^{10}$

\section{Adequate time for implementation and adaptation}

Longevity of water resource management arrangements may reflect their success, but their success may also depend on their longevity. Time is needed to develop basin-scale institutional arrangements, to experiment with alternatives and engage in trial-and-error learning. Time is needed for trust building, so water users begin to accept new

\footnotetext{
${ }^{9}$ The expression "formal or informal" is used here to distinguish between "rights" that are institutionalized to the point of legal cognition and enforceability, and "rights" that are norms of entitlement or obligation. Our use of the word "rights" is not meant to specify the former or exclude the latter. For our purposes, what is important is not the form in which the right is expressed, but its recognition as binding among stakeholders.

${ }^{10}$ Another characteristic related to ease of reaching resource management agreements is whether the water rights system allows carry-over of unused water rights from one time period to another. "Use it or lose it" systems, in which water not used in the current period cannot be claimed or used in a later period, create unhelpful incentives for water users-e.g., trying to enlarge their rights (even resorting to cheating or waste) to guard against uncertainty, over-investing in conveyance capacity and under-investing in storage capacity, etc. Systems which assure water users that forgoing some use today will not diminish their future right, or even allow them to store water in one period for use in the next, lower the costs of reaching and sustaining allocation agreements among users.
} 
arrangements and gradually commit to sustaining them. And time is needed for resource management actions to be translated into observable and sustained effects on resource conditions. Several successful examples of basin-level institutions, including some in this study, took decades to design and implement.

The relationship between time and success is complex, though. As noted earlier, adaptability is important; water users need to be able to modify arrangements in response to changed conditions. On the other hand, patience is important, too-changing institutions quickly because a new approach that has not succeeded can erode stakeholders' willingness to commit their time and effort to the next reform. We are not in a position to specify a "magic number" of years, quarters, months, or whatever that central governments and basin stakeholders should bear with a decentralization effort in order to see it bear fruit. But time must be taken into account as a factor likely to influence the success of implementation of decentralization initiatives.

\subsection{The internal configuration of basin-level institutional arrangements}

Successful implementation of decentralized water resource management will also depend on features of the basin-level arrangements created by stakeholders and/or central government officials.

\section{Presence of basin-level governance institutions}

A prerequisite of successful resource management is governance-arrangements by which stakeholders articulate interests, share information, communicate and bargain, and take collective decisions. Basin-level governance is essential to the ability of water users to operate at multiple levels of action, which is a key to sustained successful resource preservation and efficient use (Ostrom 1990). Water management at the basin level is less likely to be achievable nor sustainable without the establishment and maintenance of basin-scale governance arrangements. The existence of governance arrangements is a necessary rather than a sufficient condition, however, and we do not expect to find success everywhere we find basin-scale organizations.

\section{Clarity of institutional boundaries and match to basin boundaries}

This variable refers to an institutional characteristic, namely, whether and to what extent the institutional arrangements for water resource management have boundaries that are clearly defined and reasonably well matched to the basin. This is one of the variables identified by Ostrom (1990) as a feature of long-enduring common-pool resource management institutions.

The importance of boundaries and their fit to the resource derives from their relationship to collective decision making. Ill-defined or poorly-fitted boundaries may include in collective decision making individuals or communities who are not actually in the basin, or exclude others who are. Either mismatch detracts from the efficiency and efficacy of collective decision making arrangements-needed information is missing, extraneous information is included, arrangements for distributing costs and benefits cannot approach complete fairness, and some users can exploit others with impunity. All other things being equal, we would expect to find successful implementation of decentralized water resource management in cases where basin-level institutions have 
clearly defined boundaries that are reasonably well-matched to basin boundaries, and where responsibilities of organizations within the basin are clear to the stakeholders.

\section{Recognition of sub-basin communities of interest}

Although water resources within a basin are interrelated, water users have distinct communities of interest. Downstream users' perspectives on water quality differ from upstreamers. Water users in an area overlying groundwater resources have different views of drought exposure than users in other parts of the basin. Municipal and industrial users perceive the value of water supply reliability differently than agricultural users do.

These distinctions have implications for the prospects of securing stakeholders' commitment to decentralized water resource management arrangements, and thus to the success and sustainability of those arrangements. Thus, while basin-level governance and management arrangements are essential, the recognition of sub-basin communities of interest may be nearly as important.

Recognition can include mere representation (i.e., a guaranteed voice in basin decisions), but it need not be limited to that. Basin-level decision making arrangements can also be constructed to assure that communities of interest must reach agreement on resource management decisions. This deeper level of recognition can help prevent situations where one community of interest within a basin is able to exploit another, which can certainly happen under a simpler decision rule such as a majority vote.

Of course, transaction costs increase as such assurances are issued to each subgroup within a collectivity, so this variable too would likely reach and pass a threshold beyond which additional institutionalized recognitions of sub-basin communities become counter-productive. Short of that threshold, though, recognition of sub-basin communities of interest and the adoption of basin-level decision making arrangements that minimize the prospects of one group exploiting another should support the trust and reciprocity that are important to the emergence and sustainability of basin-level arrangements in decentralized water resource management systems.

\section{Availability of fora for information sharing and communication}

Especially in water resource management, where there can be many indicators of water resource conditions and management performance, fora for information sharing are vital to reducing information asymmetries and promoting cooperation. Since information will not automatically be perceived the same way by all stakeholders, and the implications of information about resource conditions will differ among communities of interest within the basin, it is also important that there be regular fora in which basin stakeholders can communicate. All other things being equal, we expect to find successful examples of decentralized water resource management more frequently among cases where there are basin-level fora for information sharing and communication among stakeholders.

\section{Availability of fora for conflict resolution}

Disagreements among stakeholders will arise in any natural resource management setting. The success and sustainability of decentralized management efforts therefore depend also on the presence of fora for airing and resolving conflicts. All other things being equal, successful implementation of decentralized management is more likely in settings where institutional arrangements include fora for conflict resolution. 


\section{Case Study Methodology}

The factors discussed above will not all affect with equal significance the decentralization in each location. The emergence and path of river basin management will be affected profoundly by some of these variables, slightly by others, and not at all by some. A case study approach was pursued for this study in order to examine closely the processes of institutional change as well as the current situation. Institutional analysis in a case-study setting consists largely of determining which institutional factors in what combination appear to have been linked to outcomes. Furthermore, many of the variables listed above have subjective components, and would be assessed differently by different participants and observers. It therefore has been essential in these case studies to interview several individuals with a variety of perspectives.

Team members conducted site visits to each basin. Visits were preceded by the selection of an area expert who prepared a background paper on the basin and arranged interviews with basin stakeholders. Background papers for all case study visits are based on a common outline. During the site visits, team members conducted interviews focused on understanding the processes of institutional origin and change, and the performance of water management institutions at sub-basin, basin, and national scales, matters that were within the knowledge of the interviewees. Each visit was used also for collection of published material on the basin. After each visit, team members combined their notes from the interviews, revisited and revised the basin background paper, reviewed other materials, and composed working papers summarizing and analyzing each case (Blomquist et al. 2004abcde; Bhat et al. 2004; Formiga-Johnsson and Kemper 2005ab). Those working papers are thus based on a combination of sourcesdocumentary materials on the basin and the various governmental and non-governmental organizations at work there, the background paper prepared for the visit, and the interviews conducted during the site visit. The purpose of this comparison paper is to draw together information across the cases relating to the theoretical framework developed for and employed in this research study.

\section{Summary Data on Characteristics of the River Basin Organizations, Decentralization Reforms, and Approaches to Stakeholder Involvement}

The cases in this study varied on a number of dimensions. In this section, we present some summary information about the eight cases, beginning with the principal water management problems confronted by basin stakeholders. Efforts to compare and assess the experiences of these cases in implementing integrated water resource management at the river basin level must begin with an understanding of what problems water users and managers have been attempting to solve.

Table 1 presents the three or four most important water management challenges in each basin, as understood from our background research and our interviews during site visits. For each basin, problems are listed in order of decreasing priority or severity (thus, for example, pollution appears as a problem in five of the cases but is listed first for cases such as Brantas and Warta, while it appears in the Guadalquivir case as a lower priority concern than scarcity). In some basins, water supply problems received greatest emphasis in the design and operation of management efforts, in others water quality. 


\begin{tabular}{|l|l|}
\hline \multicolumn{2}{|c|}{ Table 1. Principal water management problems faced in each basin } \\
\hline AltoTietê (Brazil) & Pollution, urban development in headwaters, scarcity, flooding \\
\hline Brantas (Indonesia) & Pollution, flooding, seasonal water scarcity \\
\hline Fraser (Canada) & Flooding, pollution, inter-sectoral conflict \\
\hline Guadalquivir (Spain) & $\begin{array}{l}\text { Scarcity and water allocation, drought exposure, flooding, } \\
\text { pollution }\end{array}$ \\
\hline Jaguaribe (Brazil) & $\begin{array}{l}\text { Scarcity and water allocation, water storage, drought exposure, } \\
\text { inter-sectoral conflict }\end{array}$ \\
\hline $\begin{array}{l}\text { Murray-Darling } \\
\text { (Australia) }\end{array}$ & $\begin{array}{l}\text { Scarcity and water allocation, inter-sectoral conflict, river } \\
\text { ecology }\end{array}$ \\
\hline Tárcoles (Costa Rica) & Pollution, flooding, erosion \\
\hline Warta (Poland) & Pollution, flooding, seasonal water scarcity, drought exposure \\
\hline
\end{tabular}

The cases also differed on a variable that our theoretical framework regarded as potentially significant: whether the development of institutional arrangements for water management at the basin level had originated as a central government reform effort, or as an effort initiated by stakeholders within the basin. Although categorizing them dichotomously overlooks subtleties and compresses multiple influences present in some cases, Table 2 distinguishes usefully between the origins of the basin management reforms in the eight cases. The Brazilian cases (Jaguaribe and Alto Tietê) require some additional notation because of the federal nature of Brazil's governmental structure: creation of basin institutions originated with state government action in those basins rather than directly from national government action; nevertheless, this would correspond in our theoretical framework with a "top-down" initiative rather than one started within the basin by stakeholders. ${ }^{11}$

\begin{tabular}{|l|l|}
\hline \multicolumn{2}{|c|}{ Table 2. Top-Down and Bottom-Up Creation of Basin Organization } \\
\hline \multicolumn{1}{|c|}{ Central-government initiated } & \multicolumn{1}{c|}{ Stakeholder initiated } \\
\hline Brantas & Fraser \\
\hline Guadalquivir & Murray-Darling \\
\hline Warta & Tárcoles \\
\hline Jaguaribe (national-to-state, then state-to-local) & \\
\hline $\begin{array}{l}\text { AltoTietê (state initiated, with parallel strong } \\
\text { stakeholder support) }\end{array}$ & \\
\hline
\end{tabular}

Where a central government initiated the development of basin management arrangements, it could have occurred as a singular act applying to just one basin or as part of a broader water policy reform-for example, creating basin-scale organizations throughout the country as Poland has done. These distinctions are presented in Table 3.

\footnotetext{
${ }^{11}$ By contrast, the origin of institutions in the Murray-Darling case started with the states in their role as basin stakeholders contesting over supply allocation from an interstate river. Thus for our purposes stateinitiated action in that case is classified as stakeholder-initiated action. The state-initiated actions in the Brazil cases involved a state government directing the creation of a basin management organization within its borders in much the same fashion as a national government might create one in a unitary system
} 
Not surprisingly, the three stakeholder-initiated cases from Table 2 all appear in Table 3 as cases where creation of basin management arrangements was specific to that basin.

\begin{tabular}{|l|l|}
\hline \multicolumn{2}{|c|}{ Table 3. Basin management reform accompanied by/part of broader } \\
decentralization reform?
\end{tabular}

It also became apparent that, for some cases, supranational organizations such as The World Bank and the European Union had been influential in the development or modification of basin management programs or institutions. Both Spain and Poland have moved substantially toward IWRM (particularly in regard to water quality protection and water pricing) in response to the EU Water Framework Directive. World Bank promotion of IWRM and stakeholder involvement influenced the creation of the basin management organizations in Ceará state in Brazil (the Jaguaribe case) and the continuity of the basin management corporation approach in Indonesia (the Brantas case). The Interamerican Development Bank supported the Tárcoles Commission. A World Bankfinanced project in the state of Sao Paulo supported the development of legislation that would have influence on the instruments for riverbasin management in the Alto Tietê basins and on its institutions, such as the Headwaters Protection Law and the water pricing law.

\begin{tabular}{|l|l|}
\hline \multicolumn{2}{|c|}{ Table 4. Presence of Supra-National Influence on Creation of Basin Institutions } \\
\hline Supra-national influence present & Supra-national influence not present \\
\hline Brantas (World Bank) & Murray-Darling \\
\hline Guadalquivir (EU) & Fraser \\
\hline Warta (EU) & \\
\hline Jaguaribe (World Bank) & \\
\hline Tárcoles (IADB) & \\
\hline Alto Tietê (World Bank) & \\
\hline
\end{tabular}

\footnotetext{
${ }^{12}$ The decentralization reform in Indonesia started only after the process started in the Brantas basin. Nevertheless, especially the broader process has had a major influence in recent years, including deepening the deconcentration process to a real decentralization process in the Brantas basin.

${ }^{13}$ Initial creation of the basin management agency in the Guadalquivir case occurred in concert with the central government's creation of a number of such agencies in 1926-27. Significant reorganization of the basin agency and changes in its responsibilities took place in 1985 and 1987 as part of a national water policy reform.
} 
Basin-scale organizations have been created in each of the eight cases, but they differ in structure and type. Each basin organization is described at length and in detail (see their corresponding Working Papers). Table 5 truncates those descriptions for ease of comparison. As shown, two of the cases featured state companies, two involved central government agencies operating within nationally-defined basin boundaries, and the other four were unique variations (one inter-governmental commission, one quasigovernmental commission, one nongovernmental basin council, and one hybrid basin committee/basin agency structure).

\begin{tabular}{|l|l|}
\hline \multicolumn{2}{|c|}{ Table 5. Nature of basin organization } \\
\hline Alto Tietê & River basin committee supported by a river basin agency \\
\hline Brantas & State company, under supervision of national water resources agency \\
\hline Fraser & Nongovernmental organization \\
\hline Guadalquivir & Central government agency at basin scale \\
\hline Jaguaribe & $\begin{array}{l}\text { River basin committees and commissions supported by a state water } \\
\text { resources management company }\end{array}$ \\
\hline $\begin{array}{l}\text { Murray- } \\
\text { Darling }\end{array}$ & $\begin{array}{l}\text { Intergovernmental basin commission, with a self-financed division for } \\
\text { operating infrastructure on Murray River stem }\end{array}$ \\
\hline Tárcoles & $\begin{array}{l}\text { Quasi-governmental river basin commission recognized by central } \\
\text { government }\end{array}$ \\
\hline Warta & Central government agency at basin scale \\
\hline
\end{tabular}

Because IWRM at the river basin level could involve a range of responsibilities and activities, it is not surprising that the cases we studied differed in the functions they perform. Some had authority to allocate water to users and others did not. Many but not all were responsible for water quality. A few were engaged in setting and/or collecting water tariffs. Some operated dams, reservoirs, and other physical facilities. Table 6 indicates which among six types of responsibilities were performed by the basin-scale organizations studied in the eight cases. The only function performed by all was planning and coordination-all developed basin management plans and/or coordinated activities among multiple governmental and nongovernmental entities present within the basins.

Although management at the basin level is uniformly promoted as a way of increasing stakeholder involvement, there is no similarly uniform prescription for how this should be done. As expected, the eight cases we studied demonstrated a variety of means of organizing stakeholder participation and soliciting stakeholder input into basin management decisions, summarized in Table 7. Two of the cases, Brantas and Warta, had no established stakeholder organization (committee or other type) during the time of our study, although one (Brantas) had a program of outreach and communication between basin agency personnel and various individual stakeholders in the basin and the other (Warta) is now developing a regional water management council under the direction of a national law governing the structure and operation of basin management agencies. Other cases, such as the Alto Tietê and Fraser basins, had elaborate and multi-scale structures. Jaguaribe had numerous sub-basin user committees and commissions, but only the State Water Resources Management Company (which provides technical support to these) 
operates at the basin scale, and Murray-Darling has a basinwide Community Advisory Committee but not sub-basin ones. The Guadalquivir and Tárcoles cases have ostensibly representative structures incorporating a variety of stakeholders, although interviewees indicated that some bodies did not meet regularly and that the most broadly representative ones may not have substantial input into basin management decisions.

\begin{tabular}{|c|c|c|c|c|c|c|}
\hline \multicolumn{7}{|c|}{ Table 6. Basin organization responsibilities } \\
\hline 悫 & 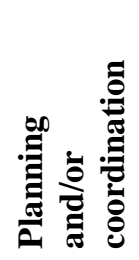 & 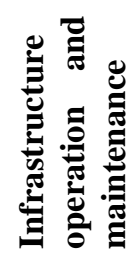 & 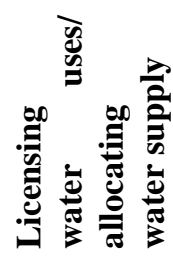 & 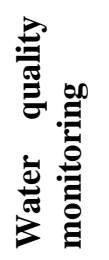 & 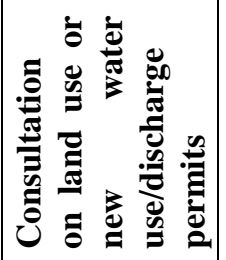 & 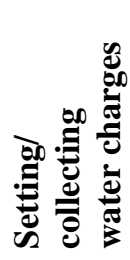 \\
\hline $\begin{array}{l}\text { AltoTietê } \\
\text { Al }\end{array}$ & $\mathrm{X}$ & & & & $\mathrm{X}$ & \\
\hline Brantas & $\mathrm{X}$ & $\mathrm{X}$ & $\mathrm{X}$ & & & $\mathrm{X}$ \\
\hline Fraser & $\mathrm{X}$ & & & & & \\
\hline $\begin{array}{l}\text { Guadalqui } \\
\text { vir }\end{array}$ & $\mathrm{X}$ & $\mathrm{X}$ & $\mathrm{X}$ & $\mathrm{X}$ & & $\mathrm{X}$ \\
\hline $\begin{array}{l}\text { Jaguaribe } \\
15\end{array}$ & $\mathrm{X}$ & $\mathrm{X}$ & $\mathrm{X}$ & $\mathrm{X}$ & & $\mathrm{X}$ \\
\hline $\begin{array}{l}\text { Murray- } \\
\text { Darling }\end{array}$ & $\mathrm{X}$ & $\mathrm{X}$ & & $\mathrm{X}$ & & \\
\hline Tárcoles & $\mathrm{X}$ & & & & & \\
\hline Warta & $\mathrm{X}$ & $\mathrm{X}$ & & & $\mathrm{X}$ & \\
\hline
\end{tabular}

Similarly varied are the means and sources of funding for the basin organizations in the eight cases. As shown in Table 8, three (Alto Tietê, Tárcoles, and Warta) rely solely on central government budget allocations at present, although there have been other sources for the Tárcoles basin commission in the past, and the basin agency and committee in Alto Tietê are supposed to have revenue from water charges in the future. Three others (Brantas, Guadalquivir, and Murray-Darling) enjoy a combination of central government support and water user charges. One (Jaguaribe) is funded entirely by water user charges, although those are collected by the state water resources management agency and then reallocated to the basin. The nongovernmental Fraser Basin Council obviously lacks the authority to levy taxes or charges on water use, and instead receives annual financial support from governments and project funds from a variety of sources.

\footnotetext{
14 The functions marked are those performed by the basin agency, as distinct from the basin committee.

15 The functions marked are those performed by the basin agency, as distinct from the basin committee.
} 


\begin{tabular}{|l|l|}
\hline \multicolumn{2}{|c|}{ Table 7. Organizational structure of stakeholder involvement } \\
\hline Alto Tietê & $\begin{array}{l}\text { Basin committee and five regional subcommittees, with } \\
\text { representation from civil society, state and local government }\end{array}$ \\
\hline Brantas & $\begin{array}{l}\text { No stakeholder advisory group or organization, but different } \\
\text { government entities representing different user sectors; basin } \\
\text { organization has stakeholder outreach program for communication }\end{array}$ \\
\hline Fraser & $\begin{array}{l}\text { Multi-sector council with representation from basin sub-regions, } \\
\text { water use sectors, and all levels of government; regional councils }\end{array}$ \\
\hline Guadalquivir & $\begin{array}{l}\text { Water Users Assembly, and several basin commissions and councils } \\
\text { with seats for water user groups, civil society, and central government }\end{array}$ \\
\hline Jaguaribe & $\begin{array}{l}\text { Numerous user commissions at reservoir and valley scales, plus sub- } \\
\text { basin committees }\end{array}$ \\
\hline Murray-Darling & $\begin{array}{l}\text { Community Advisory Committee with representation from basin sub- } \\
\text { regions, water use sectors, and state and local governments }\end{array}$ \\
\hline Tárcoles & $\begin{array}{l}\text { Multi-sector commission with representation from civil society, } \\
\text { national and local government }\end{array}$ \\
\hline Warta & $\begin{array}{l}\text { No stakeholder advisory group or organization at time of visit; one } \\
\text { being established currently }\end{array}$ \\
\hline
\end{tabular}

\begin{tabular}{|l|l|}
\hline \multicolumn{2}{|c|}{ Table 8. Financial arrangements associated with basin organization } \\
\hline Alto Tietê & $\begin{array}{l}\text { Currently, funding received from earmarked State Water Resources } \\
\text { Fund. In the future, water user charges will co-fund basin organization } \\
\text { activities. }\end{array}$ \\
\hline Brantas & $\begin{array}{l}\text { Fees from some users (industry, hydropower, and municipalities) cover } \\
\text { most operation and maintenance activities. Central government funds } \\
\text { staff salaries, flood control and major infrastructure projects. }\end{array}$ \\
\hline Fraser & $\begin{array}{l}\text { Federal, provincial, and local government annual contributions, plus } \\
\text { funds collected from sponsors of Fraser Basin Council projects }\end{array}$ \\
\hline Guadalquivir & $\begin{array}{l}\text { Funding from central government plus fees collected from water users } \\
\text { and water suppliers in the basin }\end{array}$ \\
\hline $\begin{array}{l}\text { Jaguaribe } \\
\text { Darray- }\end{array}$ & $\begin{array}{l}\text { Wampany, but cross-subsidization from other basins, especially the } \\
\text { urbanized basin of the Greater Fortaleza region }\end{array}$ \\
\hline Tárcoles & $\begin{array}{l}\text { Fasin commission funded by national government and states; } \\
\text { management of Murray River infrastructure by fees on bulk water users } \\
\text { provided by foundations and Interamerican Development Bank }\end{array}$ \\
\hline Warta & Budget allocation from central government \\
\hline
\end{tabular}

The eight cases also varied notably with respect to the continuity of central government support from the beginning of the decentralization process to the present. Support often includes financial assistance, but also supportive central government policies and a demonstrated willingness on the part of central government offices to enable adjustments of basin management arrangements when needed. Table 9 condenses 
this distinction into two categories, continuous and discontinuous central government support since the decentralization process began.

\begin{tabular}{|l|l|}
\hline \multicolumn{1}{|c|}{ Table 9. Continuity of central government support through decentralization process } \\
\hline \multicolumn{1}{|c|}{ Continuous } & \multicolumn{1}{c|}{ Discontinuous } \\
\hline Brantas & Alto Tietê \\
\hline Fraser & Guadalquivir \\
\hline Murray-Darling & Jaguraribe \\
\hline & Tárcoles \\
\hline & Warta \\
\hline
\end{tabular}

Undoubtedly there are more factors that could be used to characterize and contrast the eight cases, but the ones in Tables 1 through 9 above should suffice for a reasonable overview. Although it is not necessary in comparative case-study methodology to have a representative sample, it is important to have substantial differences among cases on variables of potential interest. With respect to everything from the origins of institutional development through the details of institutional structure, these eight cases plainly do meet that requirement.

\section{Overall Findings and Conclusions ${ }^{16}$}

We have already presented findings and conclusions specific to each case in a series of working papers (Blomquist et al. 2004a,b,c,d,e; Bhat et al. 2004; Formiga Johnsson and Kemper 2005a,b) Table 10 below provides a condensed statement of outcomes of decentralization and water management reforms for each case, drawing upon those papers. Also, for convenience of the reader, in an appendix to this paper we have also summarized findings for each case with respect to the four main categories of our theoretical framework (Tables A-1 through A-4).

\begin{tabular}{|l|l|}
\hline \multicolumn{2}{|c|}{ Table 10. Summary of reform outcomes and lessons } \\
\hline Alto Tietê & $\begin{array}{l}\text { Even after 15 years of reform São Paulo's new water resource } \\
\text { management system is not yet fully operational anywhere in the state } \\
\text { including in the Alto Tietê. This is closely related to inertia and lack } \\
\text { of political will on the part of the São Paulo state government to } \\
\text { adopt some of the “costlier" instruments such as charging for bulk } \\
\text { water (which would help finance water management activities) and } \\
\text { full implementation. } \\
\text { The presence of committed institutions and, above all, committed } \\
\text { water resources professionals and civil society organizations seems to } \\
\text { not have been sufficient to go further because water management } \\
\text { never reached the top of the state government's political agenda. } \\
\text { Several peculiarities of the Alto-Tietê context made it even more } \\
\text { difficult for river basin bodies to take advantage of their favorable } \\
\text { conditions and take the lead in coordinating water management. }\end{array}$ \\
\hline
\end{tabular}

\footnotetext{
${ }^{16}$ A reviewer has made useful suggestions for revising the order of presentation in this section, which will be done in a future version.
} 


\begin{tabular}{|c|c|}
\hline & 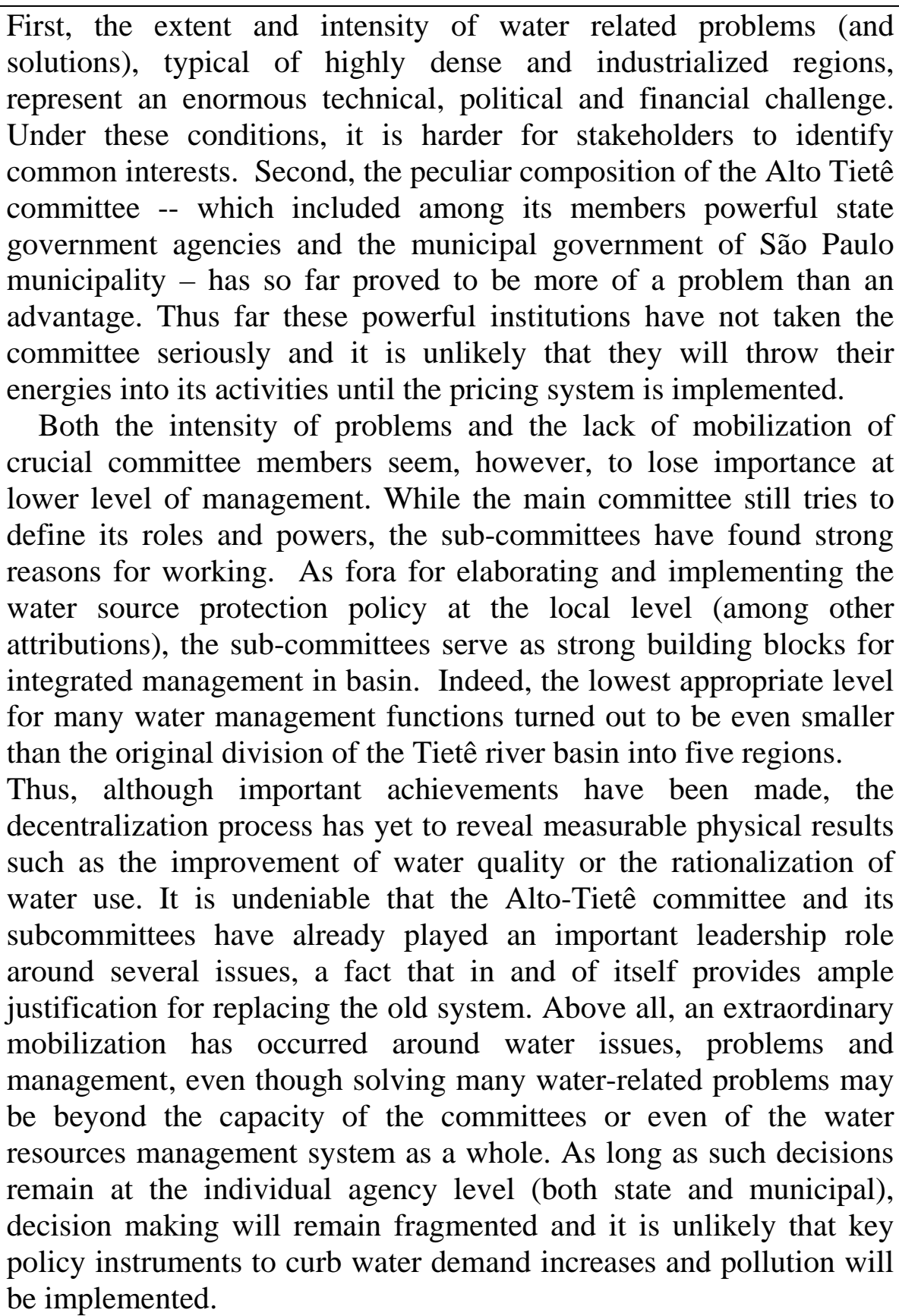 \\
\hline Brantas & $\begin{array}{l}\text { The state company, PJT I, focuses on being a reliable and accessible } \\
\text { provider for the tasks it has designated authority over: water } \\
\text { allocation (based on permits issued at the provincial government } \\
\text { level) and supply, and flood control. It has implemented a reasonably } \\
\text { good system of water allocation and management, operates a reliable } \\
\text { flood forecasting system, and appears to maintain major } \\
\text { infrastructure in fairly good condition. It was regarded by } \\
\text { stakeholders interviewed as successful in providing a source of } \\
\text { professional and unbiased information, expertise, and mediation } \\
\text { assistance. To some degree, its image as neutral and competent is }\end{array}$ \\
\hline
\end{tabular}




\begin{tabular}{|c|c|}
\hline & $\begin{array}{l}\text { aided by PJT 1's focus on a few major activities, although this is due } \\
\text { also to the fact that limits on its authority and funding prevent it from } \\
\text { addressing the full range of IWRM issues. Managing water quality, } \\
\text { catchment conditions, and river ecology remain the responsibility of } \\
\text { many entities, however, and given their growing importance the } \\
\text { authority and coordination to address them need to be improved. }\end{array}$ \\
\hline Fraser & $\begin{array}{l}\text { The NGO approach has provided a means of crossing jurisdictional } \\
\text { boundaries among levels of government in a federal system where a } \\
\text { constitution divides authority and one level of government is not } \\
\text { entirely superior or subordinate to another. It has allowed the } \\
\text { integration of First Nations (indigenous) communities and private } \\
\text { stakeholders in ways that more traditional governmental programs } \\
\text { have found difficult or impossible. It has provided a good forum for } \\
\text { information generation and sharing, since there is less concern over } \\
\text { who "owns" the information. It has succeeded in preserving a } \\
\text { reputation for objectivity and in building a more diverse financial } \\
\text { base. One key to this success has been the ability of the council to } \\
\text { promote the concept of interdependency among stakeholders. Since } \\
\text { it is an NGO, the Fraser Basin Council can take on an extremely } \\
\text { broad range of issues and in a way provides political cover for } \\
\text { participating agencies. On the other hand, it must rely on those } \\
\text { agencies for the implementation of its plans and programs. The } \\
\text { council's reliance upon consensus occasionally slows decision } \\
\text { making. On balance, however, the approach represented by the } \\
\text { Fraser Basin Council has worked well. }\end{array}$ \\
\hline Guadalquivir & $\begin{array}{l}\text { Several policy changes over the past two decades, combined with the } \\
\text { EU Water Framework Directive, have moved Spanish water policy } \\
\text { away from a sole emphasis on supply augmentation and toward } \\
\text { IWRM. Policy reform has added new and different responsibilities to } \\
\text { river basin agencies such as the one for Guadalquivir basin, and } \\
\text { representation of a broader range of stakeholders on the basin } \\
\text { agency's boards and commissions. Nevertheless, the basin agency is } \\
\text { perceived by some as still favoring irrigators' interests and focused } \\
\text { primarily on supply augmentation rather than a broader range of } \\
\text { concerns. Some of the newer functions-water licensing, demand } \\
\text { management-have been performed with less vigor and with less } \\
\text { positive results. Despite substantial investments in supply and } \\
\text { storage facilities, Guadalquivir's "water deficit" has not been erased, } \\
\text { and exposure to droughts remains a principal problem. Systematic } \\
\text { efforts to reduce non-point pollution are still lacking, and a } \\
\text { considerable amount of agricultural water use remains comparatively } \\
\text { inefficient. The Andalusian regional government has asserted itself } \\
\text { as an alternative policy forum, for greater participation by some } \\
\text { interests and discussion of some issues perceived to be neglected by } \\
\text { the basin agency. }\end{array}$ \\
\hline Jaguaribe & The devolution of federal authority over the management and \\
\hline
\end{tabular}




\begin{tabular}{|c|c|}
\hline & $\begin{array}{l}\text { operation of federal reservoirs to Ceará State has been highly } \\
\text { effective. Devolution from state to local level has been more partial. } \\
\text { Although the state agency has decentralized the allocation of strategic } \\
\text { reservoir waters to local institutions, many traditional water } \\
\text { management attributions continue under its purview. Nor has basin } \\
\text { management in this location incorporated land use or drainage, which } \\
\text { remain under the control of municipalities. The creation of sub-basin } \\
\text { committees and user commissions has increased participation by all } \\
\text { types of stakeholders, which is itself a major transformation from } \\
\text { previous practices. Stakeholder involvement has been limited largely } \\
\text { to negotiating water allocation and resolving conflict, and local } \\
\text { stakeholders still have no say in some processes that greatly affect } \\
\text { them. The financial resources of the sub-basin committees and user } \\
\text { commissions remain insecure, depending entirely on contributions } \\
\text { from state government and from their own members. At the state } \\
\text { level, though, bulk water pricing has represented an important } \\
\text { change, and has allowed the state company to gradually achieve } \\
\text { financial stability for its infrastructure operations. The case of the } \\
\text { Jaguaribe basin powerfully illustrates that (i) longstanding political } \\
\text { support is of major importance in the development and } \\
\text { implementation of water resources management reform, (ii) that } \\
\text { institutional arrangements for water resources management can } \\
\text { successfully be adapted to local conditions in order to achieve } \\
\text { positive outcomes, and (iii) that even with initial conditions that seem } \\
\text { to not favor change, decentralization can be achieved. One lesson, } \\
\text { however, cannot be drawn as yet and only the future will tell if the } \\
\text { strength of a } 12 \text {-year long decentralization process in water resources } \\
\text { management, initiated and strongly supported by a succession of } \\
\text { political leaders, and implemented by highly professional and } \\
\text { dedicated staff, is sufficient to overcome the current 'political drought } \\
\text { period' that started with the change in state and institutional } \\
\text { leadership in } 2003 \text {. }\end{array}$ \\
\hline Murray-Darling & $\begin{array}{l}\text { Murray-Darling Basin water resource management's successes in } \\
\text { gaining intergovernmental cooperation and commitment, instituting } \\
\text { mechanisms for stakeholder participation, and generating trusted data } \\
\text { are considerable. In terms of devolution of authority, stakeholder } \\
\text { participation, and financial self-sufficiency, the arrangements have } \\
\text { been generally successful. Water resource management is still driven } \\
\text { by policy elites and audit groups in each state, but much activity is } \\
\text { carried out at regional levels in local offices with almost complete } \\
\text { authority for policy implementation (including water sharing). } \\
\text { Management and operation of dams and irrigation schemes has been } \\
\text { transferred to entities designed for localized day-to-day management } \\
\text { and financial sustainability. Both urban and rural (irrigation) water } \\
\text { supply infrastructure have been weaned from government funding for } \\
\text { operation and maintenance and receive a small and steadily }\end{array}$ \\
\hline
\end{tabular}




\begin{tabular}{|c|c|}
\hline & $\begin{array}{l}\text { decreasing amount of capital funding. All levels of water } \\
\text { management are now supported by stakeholder advisory groups. }\end{array}$ \\
\hline Tárcoles & $\begin{array}{l}\text { The Tárcoles basin commission was for a period in the } 1990 \text { s able to } \\
\text { initiate and lead important basin improvement activities. } \\
\text { Agribusiness contamination of water, especially from coffee } \\
\text { processing operations, was reduced through the Voluntary Plan } \\
\text { Program. Reforestation efforts championed by the basin commission } \\
\text { helped slow the degradation. Changes of leadership at the Tárcoles } \\
\text { basin commission and its changed relationship with the Ministry of } \\
\text { Environment and Energy-a change that resulted in more central } \\
\text { government control but less central government support-have been } \\
\text { associated with a decline of the commission's activity, visibility, and } \\
\text { stakeholder participation. A number of basin management issues } \\
\text { remain unaddressed and unresolved. The Tárcoles basin still lacks } \\
\text { sewage treatment, and river water quality conditions continue to } \\
\text { worsen as the basin population grows. The water rights system in } \\
\text { Costa Rica inhibits effective demand management. The current } \\
\text { concession system does not cover groundwater use, or surface water } \\
\text { use by public hydroelectric suppliers. The tariff system for } \\
\text { agricultural water use continues to base fees on cultivated area rather } \\
\text { than water use, providing little incentive for efficient water use. } \\
\text { Furthermore, groundwater use appears to be subject to no control } \\
\text { whatever though there is evidence of overdraft in the San Jose area. }\end{array}$ \\
\hline Warta & $\begin{array}{l}\text { The Warta basin illustrates how much institutional creation and } \\
\text { policy reform can be accomplished in a relatively short period when a } \\
\text { central government makes and sustains a commitment to } \\
\text { decentralization and IWRM. Fifteen years ago, Poland lacked a } \\
\text { rational system of water tariffs, wastewater discharge controls, water } \\
\text { resource planning, or river basin-scale organizations. These are in } \\
\text { place now, although still quite new, along with bodies at the national, } \\
\text { provincial and local levels for funding water quality improvements } \\
\text { and other environmental protection projects. While much has been } \\
\text { accomplished, institutional boundaries have not always been clear, } \\
\text { and some things have proceeded quite out of phase-principally, the } \\
\text { establishment of the river basin agencies without a revenue source of } \\
\text { their own, without a structure for basin stakeholder representation and } \\
\text { participation, and a decade before the passage of the water law that } \\
\text { largely defines and authorizes their activities. Organizational } \\
\text { responsibilities and relationships have been less integrated than } \\
\text { policy. Currently there is a substantial gap between the basin-scale } \\
\text { organizations that have been created in Poland and the activities that } \\
\text { comprise IWRM, most of which have been assigned to sub-basin } \\
\text { governments. Water quality remains a great challenge in the Warta } \\
\text { basin. Rivers remain polluted with bacteriological and chemical } \\
\text { contaminants. There was a national policy to promote water storage } \\
\text { facilities such as small reservoirs, but funding has not been adequate }\end{array}$ \\
\hline
\end{tabular}




\begin{tabular}{|l|l|}
\hline & $\begin{array}{l}\text { to carry it out. Severe flooding occurred in the Warta basin as } \\
\text { throughout Poland in 1997, and the risk of flooding has not been } \\
\text { eliminated. }\end{array}$ \\
\hline
\end{tabular}

This section presents some conclusions across the case studies about important factors that were related to the degree of success in gaining stakeholder involvement, developing institutions at the river basin level for integrated water resource management, and addressing water resource problems. As discussed below, the factors that appeared to make the greatest difference among the cases were the consistency of central government political and financial support for the basin management effort, adequate revenues for the basin organization and the ability to retain those revenues within the basin for water management priorities, effective leadership within the basin, involvement of stakeholders in aspects of resource management that affect them directly, and perceptions among stakeholders of responsiveness and evenhandedness on the part of basin management organizations and officials.

In order to present the findings in a comparative framework, they are discussed in connection with a series of questions about process and performance of decentralized approaches to river basin management.

Was the active involvement of stakeholders secured? In most cases, this can be answered yes, although there are exceptions and variations as one would expect. Representation of diverse groups of stakeholders, regular and sustained opportunities for interaction, an ambitious agenda of basin management issues, and direct connection of basin management activities with matters relevant to people's livelihoods and local communities contributed to active involvement in several of the cases we observed.

As noted above in Table 7, the river basin organizations in the Warta River in Poland and in the Brantas River in Indonesia lacked organized structures for stakeholder involvement, so communication between basin management staff and stakeholders in those cases was more individualized and less regular. In the Guadalquivir basin in Spain, the number and diversity of stakeholder representatives has been expanded with reform and reorganization of the basin management agency, but some stakeholders (particularly irrigation communities) are more actively involved than others, and there were expressions of dissatisfaction from some other stakeholders with the frequency, regularity, and significance of contact with the basin management agency. In the Tárcoles basin in Costa Rica, stakeholder involvement was quite active in the 1990s as the basin commission was getting started. In the Murray-Darling case in Australia, there are multiple layers of stakeholder involvement, including rural irrigation companies and districts, regional catchment authorities, water service provider associations, a basinwide Community Advisory Committee, and state and federal government representation on the commission and ministerial council for the basin as a whole. Local stakeholders participated actively with state government personnel in establishing basin management organizations in the Alto Tietê basin in Brazil, where sub-basin committees organized around “social basin' boundaries more than hydrological ones continue to enjoy active stakeholder participation. In the Jaguaribe basin in Brazil, participation takes place along the river valley where the key infrastructure is located and around strategic multi-year reservoirs. However, for strategic reasons, the state government has little interest in 
having stakeholders from the Jaguaribe basin become actively involved in longer-term allocation decisions regarding the transfer of water into the Greater Fortaleza Metropolitan basin to meet the state capital's growing water needs. The Fraser Basin Council in Canada has succeeded through regular meeting schedules and a combination of basin wide and sub-basin regional councils to secure and maintain a high level of stakeholder engagement since its establishment in 1997.

What factors (from our theoretical framework, or otherwise) appear to be related to successful start-up of river basin organizations in these cases? The commitment of governmental support to the creation of stakeholder-based or stakeholder-involved organizations was a positive factor at the outset of the Tárcoles , Fraser, Jaguaribe and Alto Tietê experiences. The presence, or the prospect, of valuable infrastructure investments became a point of stakeholder interest from the beginning of the Guadalquivir and Murray-Darling cases. The absence of significant cultural conflicts among basin stakeholders in most of the cases helped too.

Beyond our theoretical framework, there were other factors that proved to be important in some of the cases. One was the presence of a "champion," an influential individual who drew attention to basin problems and conditions, and who possessed the entrepreneurial skill to develop the combination of people, information, and finances to get a basin-level organization started. This was particularly important in the Brantas, Jaguaribe, Fraser, and Tárcoles cases, and to some extent with the widening of the scope of basin management issues in the Murray-Darling basin. Another factor was the presence of severe water resource problems, which proved important in all cases and which economic theory would predict but which was not made explicit in our theoretical framework. (This is a "good news-bad news" finding - the "bad news" is that problems such as flooding, pollution, scarcity, and/or inter-sectoral conflict have to reach a threshold of severity in order to stimulate collective action; the "good news" is that once they reach that threshold, collective action often follows.) A third factor was the influence of supra-national entities such as the World Bank or the European Union, mentioned previously in Table 4. Conditions or advice accompanying Bank assistance, and the desire for policies that are consistent with the EU Water Framework Directive, shaped the establishment of basin organizations, the broadening of water management issues toward an IWRM approach, or both.

Has the active involvement of stakeholders been sustained over time? The answer to this is not simple, because of the differences in stakeholder involvement noted earlier ${ }^{17}$ and the different lengths of time basin management has been undertaken. Where we did observe sustained active involvement, it appeared to be connected with stakeholder perceptions that the basin management organizations were engaged in important issues and were making (or had made) a positive difference in basin conditions, with consistency of governmental support, and with some of the same factors that stimulated stakeholder involvement in the first place such as regular and frequent interaction. These factors were present in the Fraser and Murray-Darling cases, at the sub-basin levels in the

\footnotetext{
${ }^{17}$ Cases such as the Warta and Brantas basins, for instance, which had not yet institutionalized particular mechanisms for stakeholder involvement by the time of our study, might be categorized as "not applicable" with respect to this question.
} 
Alto Tietê and Jaguaribe cases, and with respect to irrigation communities in the Guadalquivir basin.

Stakeholder involvement has waned during the past five years in the Tárcoles case, as well as in the Jaguaribe and Alto Tietê cases, and is lower among non-irrigation stakeholders in the Guadalquivir case, for similar reasons. Irregular and less frequent commission meetings in recent years and a perceived inconsistency of government support were noted by some stakeholders interviewed in the Tárcoles basin. In the Guadalquivir basin, some non-irrigation stakeholders expressed the view that they participated less because they believed their views and interests were not as welcome. The Andalusian regional government has even constructed an alternative stakeholder forum in that basin, partly as a reaction to that perception among non-irrigation stakeholders. In the state of Ceara, a change of government took place with the current government returning to more centralized policies. And in the Alto Tietê case, state government has never given full political support to some of the key reform agenda ingredients that are on the table. Over time, therefore, the activities of the Alto Tietê Committee seem to have lost enthusiasm and strength.

Was stakeholder involvement linked in a substantive way to resource management decision making (as distinct from mere stakeholder consultation)? In most cases, yes. Relatively new as well as long-lived river basin organizations had engaged stakeholders in substantive basin management decisions. Stakeholder involvement was more common with respect to basin planning, water supply allocation, and infrastructure operation, and less common with respect to setting water charges, collecting fees, flood control, monitoring basin conditions, altering land uses or infrastructure construction decisions.

In the Guadalquivir basin, operations boards that include stakeholders and agency staff make reservoir management decisions, a basinwide commission that includes stakeholder representatives decides upon the schedule and volume of water storage releases each year, and water supplies are allocated among individual farmers by management boards in the many irrigation communities of the basin. In the Jaguaribe basin, user committees at the local reservoir scale have a strong say in annual water storage and releases. In the Alto Tietê basin, the river basin committee and sub-basin committees are involved in designating headwater protection areas. Catchment management authorities in the Murray-Darling basin are increasingly involved in review of land-use changes for possible effects on water and other natural resources, irrigation companies or districts set water rates and make allocation decisions, and representatives from the three states along the main stem of the Murray River participate in decisions about the operation of dams and the management of flows in the river. During the 1990s, stakeholders in the Tárcoles basin were actively involved in a reforestation program and in the recruitment and recognition of businesses for participation in a basinwide voluntary program to reduce discharge of contaminants to the river and tributaries. Even the nongovernmental Fraser Basin Council—which does not execute policy or implement projects directly-holds "State of the Basin" conferences, issues "State of the Basin" reports, forms partnerships with other governmental and nongovernmental entities in the basin for specific projects, and lends its endorsement to an agenda of basin sustainability initiatives that appear to influence the decisions of officials at the local, provincial, and federal government levels. 
Stakeholder involvement in basin management in the Brantas and Warta basin cases has been more extensive with respect to the review of basin plans prepared by agency staff than in the making of basin management decisions or the operation of projects. This is not to diminish the importance of stakeholder involvement in planning, but simply to distinguish between the scope of stakeholder involvement in those cases relative to the other six. A further note is in order about the Warta case: at the province (voivode) level in Poland, representative boards do participate in decisions about the allocation of funding for wastewater treatment and other environmental improvement projects, although this activity is not organized at the basin scale nor does the regional water management authority for the river basin have a direct role in it. Nevertheless, the financial investments made by these provincial bodies are a very important element of improving water quality conditions throughout the river basin.

Did stakeholder involvement translate into more effective resource management? If so, why, and if not, why not? With respect to reducing exposure to flooding and better management of releases from water storage reservoirs, it is possible to say that stakeholder involvement and performance improvements in the Brantas, Guadalquivir, Jaguaribe, and Murray-Darling cases have gone hand in hand. The same can be said of reduction in the rate of deforestation in the Tárcoles basin, of improved treatment of industrial wastewater and reduced use of the river for waste discharge in the Fraser basin, and of headwater area protection in the Alto Tietê basin. Measurable improvements to wastewater treatment in the Warta basin have resulted from the financial investments of the provincial funds for environmental protection and water management.

On the other hand, stakeholder involvement can perpetuate impediments to improved water resource management. Irrigation communities and basin agency personnel in the Guadalquivir basin, for example, have devoted decades to the construction of additional dams and reservoirs, yet the basin's annual "water deficit" remains in place. Furthermore, improvements to the efficiency of agricultural water use there have been piecemeal, unlicensed uses of water for irrigation continue to grow, and the issue of agricultural contributions to water pollution has been addressed only recently and partially. In the Brantas basin, agricultural users consume the largest share of water supply but have managed to remain exempt from water tariffs that are paid by municipal, industrial, and hydropower users. In the Tárcoles basin, public hydropower producers make the most, albeit non-consumptive, use of surface water yet are exempt from water licensing and tariff requirements that apply to other users (including private hydropower producers). IWRM and stakeholder involvement are uniformly promoted in the professional and policy literatures as leading toward improved resource management; what is less often noted is the prospect for active stakeholder involvement to translate into forms of stakeholder protectionism, particularly the political influence of water use sectors is asymmetric. This does not mean that stakeholder involvement and an IWRM approach to river basin management are bad ideas, only that a more careful analysis is warranted.

Whether water management improvements were large or small, and whether their benefits and burdens were distributed evenly or unevenly, there were social benefits to the functioning of participatory structures and to the establishment of basin-scale and sub-basin organizations for water management. The degrees of success and the longevity 
of basin management efforts may vary across cases, but we would conclude that the social and institutional capital of all eight are richer due to the actions that have been taken, and they are in a better position to meet future water management challenges than if they had not taken the steps they already have.

Were improvements in resource management sustained over time and as conditions changed? Despite improvements, significant water resource management problems remain in all of the cases we studied. In several cases, this is due to changing conditions to which management entities have not adapted fully. For instance, the long-lived management regime of the Murray-Darling basin is wrestling with more recently recognized problems of dryland salinity and deteriorated river ecology. The equally long-lived Guadalquivir basin agency has yet to fully cope with its enlarged responsibilities for water licensing and demand management, and with water supply reliability and flood protection for a growing and rapidly urbanizing population. In the Warta case, flood risks have diminished and the quality of large-scale municipal and industrial wastewater discharges has improved, but lack of integration of water supply management with land use development and jurisdictional gaps between the issuance of permits and the enforcement of compliance with them have contributed to the rise of seasonal water scarcity and accumulating groundwater overdraft in portions of the basin. In the Tárcoles case, early successes in raising awareness of the negative impacts of deforestation and industrial water discharges have not been sustained, and in the meantime the basin's population and economy have grown rapidly and the problems of land use, erosion, and water pollution have continued to increase. In the Jaguaribe case, water security in drought conditions for all stakeholders has significantly increased by more transparent and effective planning, and operation and maintenance of infrastructure. Environmental problems, which used to not even be contemplated due to the overriding issue of water scarcity and allocation are now a second-generation issue being raised and starting to be addressed. In the Alto Tietê case, the main problems of Sao Paulo's water supply have not been sufficiently tackled and keep growing. Only at the subbasin levels are some activities carried out, but these are not enough for such a metropolitan area.

In most of the cases, the principal water resource problems that gave rise to the establishment of basin and sub-basin organizations are being addressed, and improvements have occurred. As newer problems have come to the fore and the scope of management responsibilities expanded, however, it is too early to tell in several of the cases whether and how well the arrangements developed for other problems and functions will cope with them.

What factors (from our theoretical framework or otherwise) appear to be related to the longevity of decentralized arrangements in some cases and their demise in others? The consistency of central government support for basin management, stakeholder involvement, and water policy reform has emerged as one of the most important factors distinguishing cases with greater levels of success and stakeholder participation from those with less. Consistency of support may be as important as magnitude of support over the long run. Magnitude matters, as can be seen in the negative effects of insufficient central government funding on basin management in the Warta and Tárcoles (post-1998) cases. By contrast, organizations such as the Murray-Darling Basin Commission, the Fraser Basin Council, and the Confederacion Hidrografica del 
Guadalquivir have been able to sustain multi-year basin planning and projects thanks to relatively consistent levels of central (and in the Fraser and Murray-Darling cases, state/provincial and local) support for their work.

Related variables concerning financial resources and financial autonomy mattered to longevity as well. Most revenue generated from water users in the Guadalquivir, Murray-Darling, and Brantas basins, for example, remains within or is returned to the basin for improvements and operations there. Basins that are wholly dependent on central government allocations (Warta and Alto Tietê, for example) have had a more difficult time establishing their own priorities and undertaking substantial projects.

The matter of top-down versus bottom-up initiation of reform seems to make a difference, as predicted, but this needs to be considered along with other variables from our theoretical framework-prior experience at the local level with self-governance and service provision, and consistency of central government support through periods of transition. Thus, while stakeholders initiated the creation of basin organizations in the Fraser, Murray-Darling, and Tárcoles basins, the first two are in countries with more experience of local autonomy than the third, and central government support has been more variable in the latter as well

As noted earlier, the relatively low levels of cultural conflict among stakeholders in most of these cases was a positive factor. In the Jaguaribe case, differences between the metropolitan area of Fortaleza in an adjacent basin and the agricultural communities in the Jaguaribe basin from which water is being withdrawn to supply Fortaleza have contributed to the persistence of state-level decision making and to the delay in full devolution of management functions to the basin level. The Fraser Basin is another exception, where decades of tension between First Nations and the Canadian federal and provincial governments was one of the factors that contributed to the decision to form a non-governmental basin organization that could incorporate representatives from each.

In some basin management arrangements, explicit provisions were made for recognizing and involving sub-basin communities of interest. As noted in Section 2, this can be an important element of successful basin management arrangements, especially in larger basins and in basins where different water use sectors dominate different areas. The Murray-Darling basin management scheme relies strongly upon the states (New South Wales, Victoria, South Australia, and Queensland) and the Australian National Territory (Canberra) to manage several aspects on water supply and use within their borders, and New South Wales and Victoria have in turn established catchment management authorities to organize land use and water protection practices at the subbasin watershed scale. Spanish water law and the structure of the river basin agency in the Guadalquivir basin recognize irrigation communities that allow farmers within a community to allocate supplies and resolve conflicts. The Alto Tietê basin contains five basin sub-committees capable of giving closer attention to the distinct problems and resources of areas within the basin. The Jaguaribe basin contains user communities organized down to the reservoir scale. The basin management authority in the Warta basin has three local offices, although they are engaged primarily in infrastructure operation and maintenance and play a very limited role on other aspects of resource management. Even the nongovernmental Fraser Basin Council has regional councils and regional coordinators for five sub-basins. One proposal for enhancing the river basin 
commission in the Tárcoles has been the establishment of upper, middle, and lower area committees, but this has not occurred yet.

Finally, we noted earlier the importance of "champions" in getting basin management institutions started. Here, we add that the departure of such a "champion" is also a delicate moment in the life of those institutions. This has been evident in the Fraser, Tárcoles , Jaguaribe and to a certain extent Alto Tietê cases. Nevertheless, the institutions in most of those cases have survived and basin management activities continue, so it is equally important not to presume that the departure of a champion must spell doom for a basin management effort.

Table 11 compresses the discussion above into a visual representation of the presence or absence (or in some instances, the partial or inconsistent presence) of a variety of institutional factors in the eight cases.

\begin{tabular}{|c|c|c|c|c|c|c|c|c|}
\hline \multicolumn{9}{|c|}{ Table 11. Summary of basin characteristics and performance } \\
\hline & $\begin{array}{l}\frac{D}{\sigma} \\
\frac{0}{0} \\
\frac{0}{0}\end{array}$ & 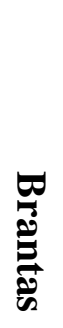 & 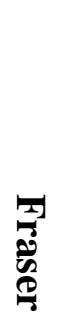 & 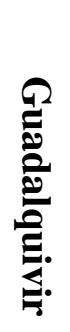 & & 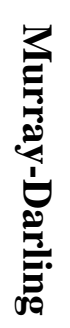 & 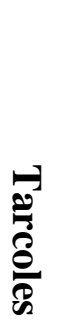 & 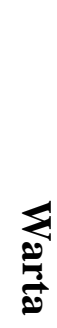 \\
\hline $\begin{array}{l}\text { Central government support for creation of } \\
\text { stakeholder-based organizations }\end{array}$ & $\mathrm{X}$ & & $\mathrm{X}$ & & $\mathrm{X}$ & & $\mathrm{X}$ & \\
\hline Presence of influential leader or “champion” & & $\mathrm{X}$ & $\mathrm{X}$ & & $\mathrm{X}$ & ? & $\mathrm{X}$ & \\
\hline Presence or prospect of infrastructure investment & & & & $\mathrm{X}$ & & $\mathrm{X}$ & & \\
\hline Presence of severe water resource problems & $\mathrm{X}$ & $\mathrm{X}$ & $\mathrm{X}$ & $\mathrm{X}$ & $\mathrm{X}$ & $\mathrm{X}$ & $\mathrm{X}$ & $\mathrm{X}$ \\
\hline Influence of supranational organizations & $\mathrm{X}$ & $\mathrm{X}$ & & $\mathrm{X}$ & $\mathrm{X}$ & & $\mathrm{X}$ & $\mathrm{X}$ \\
\hline $\begin{array}{l}\text { Magnitude of central government support adequate } \\
\text { for effective decentralization/basin management? }\end{array}$ & & ? & $\mathrm{X}$ & $\mathrm{X}$ & & $\mathrm{X}$ & & \\
\hline Consistency of central government support & & $\mathrm{X}$ & $\mathrm{X}$ & $\mathrm{X}$ & & $\mathrm{X}$ & & \\
\hline Basin-generated revenue remains in basin & & $\mathrm{X}$ & & $\mathrm{X}$ & & $\mathrm{X}$ & & \\
\hline $\begin{array}{l}\text { Basin management reform was “bottom-up” or } \\
\text { mutually desired }\end{array}$ & $\mathrm{X}$ & & $\mathrm{X}$ & & & $\mathrm{X}$ & $\mathrm{X}$ & \\
\hline Social and cultural distinctions among stakeholders & & & $\mathrm{X}$ & & $\mathrm{X}$ & & & \\
\hline $\begin{array}{l}\text { Recognition and involvement of sub-basin } \\
\text { communities of interest }\end{array}$ & $\mathrm{X}$ & & $\mathrm{X}$ & $\mathrm{X}$ & $\mathrm{X}$ & $\mathrm{X}$ & & ? \\
\hline Active, regular stakeholder participation secured? & $\mathrm{X}$ & & $\mathrm{X}$ & ? & ? & $\mathrm{X}$ & ? & \\
\hline $\begin{array}{l}\text { Stakeholder participation linked with management } \\
\text { decision making? }\end{array}$ & $\mathrm{X}$ & & ? & $\mathrm{X}$ & $\mathrm{X}$ & $\mathrm{X}$ & ? & ? \\
\hline $\begin{array}{l}\text { Stakeholder involvement associated with improved } \\
\text { management? }\end{array}$ & & $\mathrm{X}$ & ? & $\mathrm{X}$ & $\mathrm{X}$ & $\mathrm{X}$ & ? & ? \\
\hline Management improvements sustained over time? & $?$ & $\mathrm{X}$ & $\mathrm{X}$ & ? & $?$ & $?$ & & ? \\
\hline
\end{tabular}




\section{Implications for Policy and Research}

One important finding from these case studies is that, while the level of economic development of the nation and the basin can clearly make the creation and sustaining of basin-level institutions easier or harder, there is no reason to believe that improvements in water resource management are limited to wealthier settings. Notable improvements can be and have been realized in a variety of settings, and sometimes very early in the life of basin organizations and stakeholder participation initiatives.

Although river basins are important hydrologically, ecologically, and economically, not all aspects of stakeholder participation and not all decisions and activities that contribute to IWRM have to be organized at the basin scale. As we have seen in these cases, a variety of scales have been used. The "lowest appropriate level" for some water resource management functions may therefore be a sub-basin, a local or regional unit of government, or a hybrid unit sometimes referred to as the "social basin," (e.g., the basin subcommittees in the Alto Tietê case).

In addition, it is vital to recognize that the establishment of participatory and decision making structures involves shifts of power, and this can be a controversial and complicating factor. Even in settings where there was a desire to have decentralized basin management, power considerations can prevent that desire from being realized so that this has not always entirely been implemented. Efforts by the Andalusian regional government to exercise more leadership over basin management in the Guadalquivir case, the efforts of users in the Jaguaribe basin to gain more influence in decision making, especially with regard to infrastructure, the desire of the state company in Indonesia to also take on pollution control which is currently the responsibility of provincial government, are only a few examples of the ways in which jurisdictional and other power-related considerations are likely to arise. The political economy will always play a role in the water sector and is an important factor to be borne in mind.

Finally, for a number reasons described in this paper, decentralization reforms and the establishment of river basin management with active stakeholder involvement are processes that take time, even decades. This is why consistency of support is so important. So too is the ability to adapt and modify basin management arrangements in response to changed situations. Central governments and external organizations wishing to promote integrated water resources management on a river basin scale should be prepared to sustain their commitment to reform, across changes of administration and through good and bad times. 


\section{References}

Alaerts, G.J. 1999. “Institutions for River Basin Management. The Role of External Support Agencies (International Donors) in Developing Cooperative Arrangements”, International Workshop on River Basin Management - Best Management Practices, Delft University of Technology/River Basin Administration (RBA), The Hague, October 27-29, 1999

Allee, David J. 1988. "River Basin Management." Proceedings of an Engineering Foundation Conference: the Role of Social and Behavioral Sciences in Water Resources Planning and Management. New York: NY.

Bhat, Anjali and William Blomquist 2004. Policy, politics, and water management in the Guadalquivir River Basin, Spain. Water Resources Research. Volume 40, W08S07

Bhat, Anjali, Kikkeri Ramu, and Karin E. Kemper 2005. Institutional and policy analysis of river basin management in the Brantas River, East Java, Indonesia. Policy Research Working Paper. Washington, DC: The World Bank

Blomquist, William 1988. "Getting Out of the Commons Trap: Variables, Process, and Results in Four Groundwater Basins,” Social Science Perspectives Journal. Vol. 2, Number 4, pp. 16-44.

Blomquist, William 1994. "Changing Rules, Changing Games: Evidence from Groundwater Systems in Southern California,” In Rules, Games, and CommonPool Resources. Elinor Ostrom, Roy Gardner, and James Walker, eds. Ann Arbor, MI: University of Michigan Press, pp. 283-300

Blomquist, William, Consuelo Giansante, Anjali Bhat, and Karin Kemper 2004a. Institutional and policy analysis of river basin management in the Guadalquivir River, Spain. Policy Research Working Paper. Washington, DC: The World Bank

Blomquist, William, Andrzej Tonderski, and Ariel Dinar 2004b. Institutional and policy analysis of river basin management in the Warta River, Poland. Policy Research Working Paper. Washington, DC: The World Bank

Blomquist, William, Brian Haisman, and Ariel Dinar 2004c. Institutional and policy analysis of river basin management in the Murray-Darling River, Australia. Policy Research Working Paper. Washington, DC: The World Bank

Blomquist, William, K.S. Calbick, and Ariel Dinar 2004d. Institutional and policy analysis of river basin management in the Fraser River, Canada. Policy Research Working Paper. Washington, DC: The World Bank

Blomquist, William, Maureen Ballestero, Anjali Bhat, and Karin Kemper 2004e. Institutional and policy analysis of river basin management in the Tárcoles River, Costa Rica. Policy Research Working Paper. Washington, DC: The World Bank

Bromley, D.W. 1989. Economic Interests and Institutions. New York: Basil Blackwell

Dinar, Ariel, Karin Kemper, William Blomquist, Michele Diez, Gisèle Sine and William Fru, 2005. “Decentralization of River Basin Management: A Global Analysis”. Draft Working Paper, Washington D.C.: World Bank. 
Easter, K. William and Robert R. Hearne 1993. "Decentralizing Water Resource Management: Economic Incentives, Accountability, and Assurance.” Policy Research Working Paper No. 1219. Washington, DC: The World Bank

Formiga Johnsson, Rosa Maria and Karin E. Kemper 2005a. Institutional and policy analysis of river basin management in the Jaguaribe River, Brazil. Policy Research Working Paper. Washington, DC: The World Bank

Formiga Johnsson, Rosa Maria and Karin E. Kemper 2005b. Institutional and policy analysis of river basin management in the Alto Tietê River, Sao Paulo, Brazil. Policy Research Working Paper. Washington, DC: The World Bank

International Conference on Water and the Environment (ICWE) 1992. The Dublin Statement and Report of the Conference. International Conference on Water and the Environment, 26-31 January 1992.

Kemper, Karin E. and D. Olson 2000. "Water Pricing: The Dynamics of Institutional Change in Mexico and Ceará, Brazil,” p. 335, Dinar, A. (ed.) Water Pricing: The dynamics of institutional change in Mexico and Ceará, Brazil, New York: Oxford University Press.

Kemper, Karin E. 1996. The Cost of Free Water. Water Resources Allocation and Use in the Curu Valley, Ceará, Northeast Brazil. Ph.D. Dissertation, Linkoping University, Department of Water and Environmental Studies: Linkoping, Sweden.

Mody, Jyosthna 2004. Achieving accountability through decentralization: Lessons for integrated river basin management. Policy Research Working Paper 3346. Washington, DC: The World Bank

Ostrom, E. 1990. Governing the Commons: The Evolution of Institutions for Collective Action. New York, NY: Cambridge University Press

Ostrom, E. 1992. Crafting Institutions for Self-Governing Irrigation Systems. San Francisco, CA: ICS Press

Vermillion, D.L. and C. Garces-Restrepo, C. 1998. Impacts of Colombia's Current Irrigation Management Transfer Program. Research Report - International Irrigation Management Institute. Colombo, Sri Lanka.

World Bank 1993. Water Resources Management: A World Bank Policy Paper. Washington, DC.

Wunsch, James S. 1991. "Institutional Analysis and Decentralization: Developing an Analytical Framework for Effective Third World Administrative Reform.” Public Administration and Development. Volume 11, pp. 431-451

Wunsch, James S. 2001. “Decentralization, Local Governance and 'Recentralization' in Africa.” Public Administration and Development. Volume 21, pp. 277-288 


\section{Appendix}

The following four tables condense findings about the eight basins with respect to the four categories of variables in our theoretical framework-contextual factors and initial conditions, characteristics of the decentralization process, central-local relationships and capacities, and basin-level institutional arrangements. More detail is available in the working papers for each case (Blomquist et al. a,b,c,d,e; Bhat et al. 2004; Formiga Johnsson and Kemper 2005a,b).

\begin{tabular}{|c|c|}
\hline \multicolumn{2}{|c|}{ Table A-1. Summary of contextual factors and initial conditions } \\
\hline Alto Tietê & $\begin{array}{l}\text { Despite a favorable socioeconomic context and the initial distribution } \\
\text { of resources among basin stakeholders seeming to favor reform, the } \\
\text { political will to advance the changes has proved insufficient. The } \\
\text { political and environmental complexities of the Alto-Tietê basin seem } \\
\text { to make it particularly difficult to implement practices involving } \\
\text { integration and participation of decision making }\end{array}$ \\
\hline Brantas & $\begin{array}{l}\text { Weak institutions, a poor legal and regulatory framework, ineffective } \\
\text { bureaucracy, and endemic corruption led, in the aftermath of the } 1997 \\
\text { Asian Financial Crisis, to policy and institutional reform assisted by } \\
\text { external donors and based upon macroeconomic management and } \\
\text { stabilization as well as governmental reform. Since 1999, the country } \\
\text { has gradually recovered macroeconomic and political stability. }\end{array}$ \\
\hline Fraser & $\begin{array}{l}\text { Economic and social conditions are conducive to successful river } \\
\text { basin management. The vast majority of land and water resources in } \\
\text { the Fraser Basin are held by the province of British Columbia, and } \\
\text { used by private individuals under lease arrangements with the } \\
\text { government. Therefore, no one interest or sector of basin users had } \\
\text { legal immunity for their claims or titles to resource use. }\end{array}$ \\
\hline Guadalquivir & $\begin{array}{l}\text { While ethnic, religious, or class divisions in Andalusian society do } \\
\text { not seem to have driven water management issues, economic } \\
\text { development seems to have had a notable effect. The Guadalquivir } \\
\text { basin was poorer and more rural than most of the rest of the country, } \\
\text { and these conditions contributed to an emphasis on the expansion and } \\
\text { protection of irrigated agriculture as the central element of the } \\
\text { region's economic and social life. }\end{array}$ \\
\hline Jaguaribe & $\begin{array}{l}\text { At the time that reform began, local conditions in the Jaguaribe basin } \\
\text { appeared for a number of reasons to be somewhat unfavorable to the } \\
\text { development of decentralized and integrated water resources } \\
\text { management. First, the basin is relatively poor. Second, participatory } \\
\text { water management ran contrary to the prevailing political culture of } \\
\text { the Ceará hinterlands (sertão), since until the reforms began, water } \\
\text { there had historically been considered either a private good, the } \\
\text { property of the owners of the lands through which it flowed or under } \\
\text { the control of the government agencies of the reservoirs within which } \\
\text { it lay (usually DNOCS). Third, Ceará had one of the most entrenched } \\
\text { oligarchies in the Northeast. }\end{array}$ \\
\hline
\end{tabular}




\begin{tabular}{|c|c|}
\hline & $\begin{array}{l}\text { Other factors favored reform. At the national level, the transition to } \\
\text { democracy, that followed the fall of Brazil's military regime in the } \\
\text { mid-1980s, was accompanied by broadened acceptance throughout } \\
\text { Brazilian society of values such as democratization, decentralization, } \\
\text { and participation in policy making. At the national level an } \\
\text { unprecedented movement within the technical water resource } \\
\text { community began to promote integrated water resources } \\
\text { management. This movement, led in large part by the Brazilian Water } \\
\text { Resources Association, had a strong impact on the dissemination } \\
\text { throughout the country of certain management models, such as water } \\
\text { use rights, pricing, and river basin level management. }\end{array}$ \\
\hline Murray-Darling & $\begin{array}{l}\text { Overall, the basin was favorable social and economic terrain for the } \\
\text { development of basin management institutions. Its semi-arid climate } \\
\text { makes water issues significant enough to stimulate action, and the } \\
\text { relative wealth and homogeneity of its population present few } \\
\text { barriers to such action. The initial distribution of resources among } \\
\text { basin stakeholders clearly has favored irrigators in the basin, who } \\
\text { account for more than } 90 \% \text { of water diversions. }\end{array}$ \\
\hline Tárcoles & $\begin{array}{l}\text { The Tárcoles basin is by far the most economically developed in the } \\
\text { country and there do not appear to be substantial cultural or religious } \\
\text { differences across groups of basin stakeholders that would inhibit } \\
\text { cooperation. Financial resources are, however, a limiting factor. The } \\
\text { Tárcoles basin is politically important and reflects inconclusive } \\
\text { national policy. There seems to be overall reluctance towards } \\
\text { decentralization to lower levels of decision-making. }\end{array}$ \\
\hline Warta & $\begin{array}{l}\text { The Warta basin does not feature significant cultural, religious, ethnic } \\
\text { or other divisions. Poland's economic conditions have led to } \\
\text { financial constraints on the government sector, limiting its ability to } \\
\text { provide either central funding or revenue autonomy adequate to the } \\
\text { tasks of IWRM at the basin scale. }\end{array}$ \\
\hline
\end{tabular}

\section{Table A-2. Summary of decentralization process characteristics}

\begin{tabular}{|l|l|}
\hline Alto Tietê & The decentralization process in the Alto-Tietê basin is marked by two
\end{tabular} distinct processes: i) decentralization from the state to the basin level, which occurred with the creation of the Alto-Tietê Committee in 1994 and, more recently, it's water agency, and; ii) further decentralization within the basin in 1997/1998, which resulted in five sub-committees at lower territorial levels.

Neither state government not local stakeholders question either the need to create complementary deliberative bodies at lower levels or the fact that basin management participants should be allowed to create and modify institutional arrangements according to their needs and circumstances. However, there is no agreement about the extent of this decentralization 


\begin{tabular}{|c|c|}
\hline Brantas & $\begin{array}{l}\text { The pursuit of a strong unitary government has historically been an } \\
\text { executive response to the sprawling archipelago's extremely high } \\
\text { level of cultural, ethnic, language, and economic diversity. The } \\
\text { decentralization process has been top-down. Passage of the new } \\
\text { Water Law, in March 2004, signals central government commitment } \\
\text { to continued reform of the water resources sector in accordance with } \\
\text { the agreed action plan developed under the World Bank assisted } \\
\text { Water Sector Adjustment Loan (WATSAL). }\end{array}$ \\
\hline Fraser & $\begin{array}{l}\text { Development of Fraser Basin Council grew out of previous but less } \\
\text { comprehensive intergovernmental projects. The construction of } \\
\text { basin-scale institutional arrangements in the Fraser Basin has been a } \\
\text { matter of integrating already decentralized organizations and } \\
\text { jurisdictions. The extent of central government recognition of local- } \\
\text { level basin governance has been positive. }\end{array}$ \\
\hline Guadalquivir & $\begin{array}{l}\text { The CHs (Confederaciones Hidrografica) are best thought of as } \\
\text { central government agencies with representative components, and the } \\
\text { balance between central control and user participation has varied over } \\
\text { time. While basin-scale institutions enjoy the recognition of central } \\
\text { government officials as legitimate water resource management } \\
\text { entities, such recognition has not been accompanied by an extensive } \\
\text { devolution of authority to basin-scale institutions. CH Guadalquivir } \\
\text { takes much of its lead from Madrid. }\end{array}$ \\
\hline Jaguaribe & $\begin{array}{l}\text { The decentralization process in the Jaguaribe basin was marked by } \\
\text { two distinct processes: i) decentralization from federal to state level, a } \\
\text { result of the increased technical, institutional and financial capacity of } \\
\text { Cearás water resource management agencies; and ii) decentralization } \\
\text { from state to local level, which occurred through the creation of } \\
\text { deliberative bodies at the river basin and lower territorial levels. The } \\
\text { creation of a state water resources agency (COGERH) was not part of } \\
\text { the original design called for in the state water law, but resulted from } \\
\text { the World Bank's insistence that the state create a water agency with } \\
\text { management, monitoring and enforcement functions, including } \\
\text { pricing and the involvement and organization of local stakeholders. } \\
\text { The fact that in } 1997 \text { COGERH took over some previously federal } \\
\text { management responsibilities represented a major step towards } \\
\text { decentralization from the federal to state level. The state-to-local } \\
\text { decentralization process has been more complex. It was a top-down } \\
\text { initiative, and upper echelons at COGERH and the State Water } \\
\text { Resources Secretariat are increasingly distrustful of the participatory } \\
\text { decision-making bodies that were created. Although the long term } \\
\text { impact of these changes on the user commissions and river basin } \\
\text { committees is still unclear, reform-oriented officials hope that the } \\
\text { high level of mobilization achieved in the basin over the last ten years } \\
\text { will make it difficult to undo the advances made thus far. }\end{array}$ \\
\hline Murray-Darling & $\begin{array}{l}\text { Primary decision making authority predominantly rests at the sub- } \\
\text { basin level with the state governments. Over time, and with the }\end{array}$ \\
\hline
\end{tabular}




\begin{tabular}{|l|l|}
\hline & $\begin{array}{l}\text { cooperation and consent of the national government, the states have } \\
\text { constructed intergovernmental arrangements to control and operate } \\
\text { Murray River flows and then to address other issues. The process has } \\
\text { been as much a matter of integration as decentralization. Central- } \\
\text { level recognition of basin governance and management has been } \\
\text { complete and consistent. }\end{array}$ \\
\hline Tárcoles & $\begin{array}{l}\text { The CRGT (Coordinating Commission for the Río Grande de } \\
\text { Tárcoles) was essentially a municipal initiative and took an active } \\
\text { leadership role. The central government partially devolved authority, } \\
\text { and was supportive of the CRGT's efforts, but there was never a full } \\
\text { recognition of the CRGT's authority to manage the basin. Since 1998 } \\
\text { the central government has neither pushed the devolution forward nor } \\
\text { terminated the commission. }\end{array}$ \\
\hline Warta & $\begin{array}{l}\text { Creation of river basin agencies and reform of water policy were } \\
\text { attempted in the same decade (the 1990s) as the overall } \\
\text { democratization of Polish government, resulting in some uneven } \\
\text { progress. Significant responsibilities for water resources planning } \\
\text { and management have been spread across basin and sub-basin } \\
\text { entities, and water law reform took several years longer than } \\
\text { originally envisioned. The central government has maintained a } \\
\text { consistent commitment to decentralization and democratization } \\
\text { reforms, including the local and basin-scale organizations that it } \\
\text { created, but financial resources have been a problem. }\end{array}$ \\
\hline
\end{tabular}

\begin{tabular}{|l|l|}
\hline \multicolumn{3}{|l|}{ Table A-3. Summary of central-local relationships and capacities } \\
\hline Alto Tietê & $\begin{array}{l}\text { The advances in state water management capacity have been } \\
\text { considerable and in some cases crucial for the survival of the basin } \\
\text { committees in this transitory phase. However, tensions and problems } \\
\text { exist between the central authorities and the local bodies and basin } \\
\text { committees are not always effective. Indeed, the São Paulo water } \\
\text { resources management system as a whole is beginning to show signs } \\
\text { of breakdown in face of the state government's incapacity to make it } \\
\text { fully operational, especially by implementing bulk water charges. } \\
\text { Water reform in São Paulo seems to need much more time. } \\
\text { Considering that the reform process is almost fifteen years old, it is } \\
\text { becoming clear that transaction costs are very high in terms of time } \\
\text { and money. So much so, that the pioneer state in water reform has } \\
\text { begun to lag behind others. }\end{array}$ \\
\hline $\begin{array}{l}\text { Much power still resides with Central Government Ministries for } \\
\text { planning and policy-making. The authority to oversee the } \\
\text { management and functioning of PJT I (the Brantas River Basin } \\
\text { Management Authority) lies with the center through KimPrasWil (the } \\
\text { Ministry of Infrastructure and Human Settlement) with the Ministry } \\
\text { of Finance exercising a fiscal oversight role. KimPrasWil has } \\
\text { supervisory control of PJT I. The Supervisory Board of PJT I, with }\end{array}$ \\
\hline
\end{tabular}




\begin{tabular}{|c|c|}
\hline & $\begin{array}{l}\text { five members comprised of Central and Provincial Government, } \\
\text { undertakes general supervision of PJT I's program, work plan, and } \\
\text { budget, and answers to the Ministry of Finance and KimPrasWil. } \\
\text { The Supervisory Board does not have a stakeholder advisory group to } \\
\text { work with or any other form of stakeholder institution. It structurally } \\
\text { reflects the authority of the KimPrasWil and Ministry of Finance over } \\
\text { basin-level interests. }\end{array}$ \\
\hline Fraser & $\begin{array}{l}\text { Financial resources and autonomy of the council are relatively strong. } \\
\text { The council members have, through the Fraser Basin Society and the } \\
\text { council's own by-laws, the demonstrated ability to create and modify } \\
\text { the institutional arrangements with which they work. The water } \\
\text { rights system, on the other hand, has strengths and weaknesses. The } \\
\text { arrangements governing rights to water and land use allow for } \\
\text { considerable management flexibility, however, the control of } \\
\text { groundwater resources is weak and represents a vulnerability in terms } \\
\text { of the overall basin sustainability effort. }\end{array}$ \\
\hline Guadalquivir & $\begin{array}{l}\text { Basin level entities such as CH Guadalquivir construct basin level } \\
\text { plans, but these plans must be submitted for national approval and be } \\
\text { consistent with the national water plan. CHs collect and maintain } \\
\text { revenue of their own for some of the services they provide but they } \\
\text { also rely on central government funding for functions established and } \\
\text { determined by central government officials. CHs have several } \\
\text { advisory bodies composed of stakeholder representatives, but several } \\
\text { of those councils also have central government representatives and } \\
\text { the CH president is still a central government designee. The central } \\
\text { government remains free to alter CHs' governance structure or } \\
\text { decision making processes with as much or as little stakeholder } \\
\text { consultation as it chooses, but the basin stakeholders do not possess a } \\
\text { comparable ability. }\end{array}$ \\
\hline Jaguaribe & $\begin{array}{l}\text { The devolution of some of federal authority over the management and } \\
\text { control of reservoirs to Ceará state has been highly effective, since } \\
\text { COGERH has developed substantial technical, administrative and } \\
\text { financial management capacities. Currently, COGERH operates and } \\
\text { manages, through its agreement with DNOCS, all major reservoirs in } \\
\text { the state, accounting for over } 90 \% \text { of the state's water storage. But } \\
\text { other aspects of water management decentralization remain } \\
\text { underdeveloped. The state has proceeded only slowly with the } \\
\text { implementation of groundwater management. The development of a } \\
\text { new water use permit system has also been slow. The basin } \\
\text { committees (which were supposed to be the most important basin } \\
\text { institution) are formal institutions that still have not found a de facto } \\
\text { place in the water management system. They lack effective technical, } \\
\text { administrative and financial support. Contrary to the national } \\
\text { framework, which places river basin committees and agencies at the } \\
\text { heart of decision-making about water pricing, Ceará has centralized } \\
\text { water charging at the state level. The committees have been limited }\end{array}$ \\
\hline
\end{tabular}




\begin{tabular}{|c|c|}
\hline & $\begin{array}{l}\text { to information dissemination, consciousness-raising and capacity- } \\
\text { building among local actors and the resolution of water use conflicts. } \\
\text { Major structural projects continue to be decided solely by the state } \\
\text { government, especially with respect to supplying water to Fortaleza. } \\
\text { Conversely, decentralization in the Jaguaribe Basin has gone furthest } \\
\text { with the user commissions, especially through the negotiated } \\
\text { allocation of water. However, within COGERH and the SRH (to } \\
\text { which COGERH is subordinate) there has been resistance to giving } \\
\text { decentralized bodies greater power over water management. The } \\
\text { result is that only the sub-basin committees have been legally created, } \\
\text { and even these have received little real support or authority. } \\
\text { Meanwhile the Jaguaribe-Banabuiú Valleys Commission - where the } \\
\text { process of participatory decision-making began and has continued } \\
\text { with great intensity - is still only an informal institution. This } \\
\text { contradictory situation has created tensions between the sub-basin } \\
\text { committees and the Jaguaribe-Banabuiú Valleys Commission. } \\
\text { Transformation of water management practices in Ceará appears to } \\
\text { need more time. }\end{array}$ \\
\hline Murray-Darling & $\begin{array}{l}\text { Generally, central-local relationships and capacities are favorable to } \\
\text { integrated water resource management. The basin management } \\
\text { participants have the ability to create and modify institutional } \\
\text { arrangements. There is considerable experience at the local and state } \\
\text { levels with self-governance and service provision. One hindrance to } \\
\text { basin-level integrated water management is the system of water } \\
\text { rights. A second hindrance is that the organizations in the basin most } \\
\text { directly associated with integrated resource management (eg., the } \\
\text { sub-basin catchment management authorities) have virtually no } \\
\text { financial resources of their own and are dependent on funding from } \\
\text { state and Commonwealth governments. }\end{array}$ \\
\hline Tárcoles & $\begin{array}{l}\text { Financial resources for the basin management effort have always } \\
\text { been limited, and CRGT has never had its own revenue stream. This } \\
\text { has severely limited the commission's ability to evolve into } \\
\text { something more than a meeting place. Cantons and municipalities do } \\
\text { perform a number of functions, so there appears to be local-level } \\
\text { experience with self-governance and service provision, rather than an } \\
\text { excessive centralization of public services. The ability of any river } \\
\text { basin commission in Costa Rica to develop and implement effective } \\
\text { water supply management policies is likely to be hampered also by } \\
\text { the weak framework of water rights allocation. }\end{array}$ \\
\hline Warta & $\begin{array}{l}\text { Overall, the water law changes in } 1997 \text { and 2001, and the merger } \\
\text { with the DDWMs (Centrally-appointed District Directorates of Water } \\
\text { Management) in 1999, have given the RWMAs (Regional Water } \\
\text { Management Authorities) more responsibilities but not additional } \\
\text { sources of revenue. The RWMAs have not fared well in the national } \\
\text { government's budgetary process. The water rights system is } \\
\text { conducive to IWRM, and the reforms since the 1990s have attempted }\end{array}$ \\
\hline
\end{tabular}




\begin{tabular}{|l|l|}
\hline & to add a basin-wide perspective to that system. Permits for water use \\
and water discharge are limited in time and quantity, and approved \\
only after consultation with stakeholders about basin conditions. \\
Fees associated with non-permitted actions or with permit violations \\
provide incentives to users and also a revenue source for \\
environmental improvement projects. Other reforms (such as \\
transferability of permits) have yet to be undertaken, but most \\
elements of the institutional infrastructure of a water rights system \\
compatible with IWRM are in place.
\end{tabular}

\begin{tabular}{|c|c|}
\hline \multicolumn{2}{|c|}{ Table A-4. Summary of basin-level institutional arrangements } \\
\hline Alto Tietê & $\begin{array}{l}\text { All of the new institutions defined in the water law have been } \\
\text { formally implemented, however, their operation is still marked by } \\
\text { imprecision and institutional overlap largely as a result of the varying } \\
\text { performance of the public representatives. Gaining influence over } \\
\text { state programs is the main challenge for all basin committees in } \\
\text { Brazil, especially for those with little or no capacity for implementing } \\
\text { a water pricing system. The subcommittees are generally considered } \\
\text { more dynamic, more effective and more important than the main } \\
\text { committee. The most important role of the subcommittees is to deal } \\
\text { with making water resources protection and urban expansion } \\
\text { compatible through the implementation of the State Water source } \\
\text { Protection Law of } 1997 \text {. The Watersource Protection law recognizes } \\
\text { that simple prohibition and policing measures for protecting strategic } \\
\text { water supply sources have had perverse effects. The new approach is } \\
\text { a dramatic departure from São Paulo's traditional sectoral approach } \\
\text { to water quantity and quality, which separated the management of } \\
\text { water from its environmental aspects, especially water pollution and } \\
\text { land use. }\end{array}$ \\
\hline Brantas & $\begin{array}{l}\text { PJT I is a state-owned company with clearly delineated management } \\
\text { responsibilities and a profit motive. This arrangement has permitted } \\
\text { the company to (i) focus on the river basin as the management unit, } \\
\text { and (ii) focus on management rather than development and } \\
\text { construction. Importantly, this structure has also endowed the } \\
\text { company with credibility that the funds it receives from water users } \\
\text { will be reapplied in the basin, an important condition to ensure } \\
\text { stakeholders' willingness to contribute to basin management } \\
\text { expenses. PJT I shares responsibility with and ultimately is } \\
\text { subservient to other political entities at provincial and national levels } \\
\text { with respect to the development of water resources management } \\
\text { policy and allocation priority. }\end{array}$ \\
\hline Fraser & $\begin{array}{l}\text { The Fraser Basin Council was designed for stakeholder information } \\
\text { sharing and communication. It also provides a means for } \\
\text { stakeholders to enter into agreements to take actions to improve basin } \\
\text { conditions, and to resolve conflicts. The council has emerged as the }\end{array}$ \\
\hline
\end{tabular}




\begin{tabular}{|c|c|}
\hline & $\begin{array}{l}\text { paramount deliberative body in the basin. In its capacity as a non- } \\
\text { governmental organization funded through a non-profit society, } \\
\text { however, the council has limited ability to implement projects. It } \\
\text { often must hand off projects to other entities for implementation. At } \\
\text { times even the council members are not entirely clear what actions } \\
\text { are within the council's scope. }\end{array}$ \\
\hline Guadalquivir & $\begin{array}{l}\text { While geographic boundaries of the river basin and CH Guadalquivir } \\
\text { fit well, institutional boundaries are less clear. The basin-level } \\
\text { institutional arrangements do recognize sub-watershed communities } \\
\text { of interest within the basin. However, only irrigation user } \\
\text { communities have formal recognition in both national law and the CH } \\
\text { organizational structure. Basin-level institutional arrangements are } \\
\text { structured to provide fora for information sharing and communication } \\
\text { among basin stakeholders and between stakeholders and CH staff. } \\
\text { The effectiveness of these structures varies. }\end{array}$ \\
\hline Jaguaribe & $\begin{array}{l}\text { Water allocation is the most prestigious activity in the basin, with the } \\
\text { greatest local impact and hence the greatest capacity to mobilize local } \\
\text { actors. This importance has recently led some representatives of the } \\
\text { Executive Board of most sub-basin committees to argue that the } \\
\text { Jaguaribe-Banabuiú Valley Commission should be dismantled, with } \\
\text { the transfer of its responsibilities to the committees, as occurred in } \\
\text { Cearás Curu River Basin. This would involve a fundamental } \\
\text { rearrangement in basin institutions, since four of the five sub-basin } \\
\text { committees are involved with the regulated valleys. In the Curu basin, } \\
\text { the transfer of power from commission to committee was more } \\
\text { simple because the territorial jurisdiction of the user commission fell } \\
\text { entirely within the geographical area of a single committee. } \\
\text { While the committees and the Jaguaribe-Banabuiu User Commission } \\
\text { are sources of controversy, all actors in the basin and at the state level } \\
\text { have shown support for the } 36 \text { reservoir user commissions. The } \\
\text { allocation process they engage in is similar to that carried out by the } \\
\text { Jaguaribe-Banabuiú Valleys Commission, but the decisions have only } \\
\text { very localized impact and transaction costs are lower. Usually, the } \\
\text { commissions include only users or groups of users directly affected } \\
\text { by water allocations in the area of hydrological influence of a single } \\
\text { reservoir, since members are mostly made up of organizations } \\
\text { working in the perimeter of the reservoirs, and in the immediate } \\
\text { downstream area. Despite the current uncertainties concerning } \\
\text { institutional boundaries, both user commissions and basin committees } \\
\text { have been promoting the resolution of water use conflicts, with the } \\
\text { support of COGERH. They have come to be perceived as the } \\
\text { legitimate forum for negotiating conflicts in terms of water allocation } \\
\text { and quantitative use, and for airing other controversial issues related } \\
\text { to water quality and environmental degradation. }\end{array}$ \\
\hline Murray-Darling & $\begin{array}{l}\text { There are basin-level governance organizations and sub-basin } \\
\text { organizations, each with firm recognition and considerable support }\end{array}$ \\
\hline
\end{tabular}




\begin{tabular}{|l|l|}
\hline & \begin{tabular}{l} 
from the state and commonwealth governments. The states \\
themselves are recognized as communities of interest within the river \\
basin, as are a number of stakeholder communities represented on the \\
Community Advisory Committee. Basin users and policy makers \\
have an array of means by which to negotiate and enter into \\
agreement for committing and combining resources for projects and \\
programs to improve basin conditions. Monitoring of basin \\
conditions is performed regularly and then consolidated by the \\
Commission staff. Clarity of institutional boundaries has been \\
somewhat reduced by the introduction of the relatively new \\
catchment management bodies. It is less clear how conflicts between \\
sub-state and sub-basin entities such as a local government and a \\
catchment management body, or between catchment management \\
bodies etc. would be addressed. \\
\hline Once it lost its central government support and its dynamic initial \\
leadership, the CRGT's status and composition left it vulnerable to \\
becoming more of a discussion forum than a governing body. The \\
prevailing and traditional view that water has to be managed by its \\
uses (drinking, irrigation, hydropower, etc) rather than in an \\
integrated fashion has been reflected and reinforced by Costa Rican \\
laws. There is considerable fragmentation and territorialism among \\
agencies and institutes at the central government level. Likewise, at \\
the local level, there is little inter-jurisdictional cooperation and \\
coordination among municipalities, which have been gaining interest \\
in entering water planning and water service business activities.
\end{tabular} \\
$\begin{array}{l}\text { Management of the Warta River basin is substantially dispersed and } \\
\text { polycentric. This federal approach, with responsibilities spread across } \\
\text { levels and units of government, allows for the recognition of sub- } \\
\text { basin communities of interest, and provides overlapping layers of } \\
\text { monitoring and enforcement of water management regulations. The } \\
\text { federated structure does not, however, lend itself to clarity of } \\
\text { institutional boundaries or a close matching of jurisdictional } \\
\text { boundaries to basin boundaries. }\end{array}$ \\
\hline Warta
\end{tabular}

